\title{
各種情報量を用いた混合層の層流一乱流遷移過程の解析
}

一宮 昌司 ${ }^{* 1}$ ，中村 育雄 ${ }^{* 2}$

\section{Analysis of laminar-turbulent transition process in mixing layer with various information measures}

\author{
Masashi ICHIMIYA $^{* 1}$ and Ikuo NAKAMURA*2 \\ ${ }^{* 1}$ Institute of Science and Technology, Tokushima University \\ 2-1 Minami-Josanjima-cho, Tokushima-shi, Tokushima 770-8506, Japan \\ ${ }^{* 2}$ Emeritus Professor, Nagoya University \\ Furo-cho, Chikusa-ku, Nagoya-shi, Aichi 464-8601, Japan
}

Received: 22 October 2016; Revised: 1 December 2016; Accepted: 12 December 2016

\begin{abstract}
In the laminar-turbulent transition process of a mixing layer formed downstream of a two-dimensional nozzle exit, an analysis was performed based on various information measures. Shannon entropy, permutation entropy and Kullback-Leibler divergence were introduced, and former studies in which they were used in the turbulent analysis were then reviewed. In the present study, the probability distribution of time series of hot-wire output voltage data was obtained, then analyzed. The aim of the investigation was to clarify the effectiveness of the analysis for the transition and turbulent flow. In addition, equations which Shannon entropy must satisfy in the turbulent flow field were derived. The Shannon entropy of the fluctuating velocity changed monotonically in the downstream direction. Thus, it appears to measure the transition process in the mixing layer. The permutation entropy of the fluctuating velocity first increased, then decreased, then increased again, and decreased finally. It reflected the increase of the fluctuating velocity and change of fluctuation manner (from periodic to irregular fluctuation) during the transition process. The Kullback-Leibler divergence based on the probability density function of the fluctuating velocity increased first, then decreased downstream, and thus did not show a monotonic change during the transition process in the mixing layer.
\end{abstract}

Key words : Transition, Turbulence, Turbulent flow, Shannon entropy, Permutation entropy,

Kullback-Leibler divergence, Probability density function, Mixing layer

\section{1. 序論}

層流から乱流への遷移過程の大きな特徴は流れの複雑さの増大である. Kolmogorov は事象の複雑さとは何か, の考察を行い(Kolmogorov, 1965, 1983), “対象記号系列 $x$ を表現する最小プログラム長さ $y$ が $x$ の複雑度である” と定義し，計算量理論の基礎を築いた。この計算不可能と証明されているコルモゴロフ複雑度を圧縮ソフトで近 似的に求める方法が後に提案された(Vitányi, 2006). 著者らは層流乱流遷移過程の定量的評価にこれを利用するこ とを考え，混合層(一宮，中村，2012)(Ichimiya and Nakamura, 2013)，平板上の突起により発生する乱流くさび(一 宮他，2014)，円管中への吹き出しによる遷移(一宮他，2015)を調へ，この客観的定量的方法の妥当性を示した. なお，一宮らは，佐藤(Sato and Saito, 1975)によるスペクトルの広がりを利用する雑然度の解析も行ったが，これ には判定が主観的であるという問題点がある(一宮他，2011b)(Ichimiya et al., 2013a).

事象の複雑さを定量化するものの一つに 1948 年に Shannon が定義した確率分布のエントロピーがある(Shannon, 1948)。これを Shannon は，情報の大きさ，選択の可能性，不確かさの度合いなどを示寸量として説明しており (Shannon and Weaver, 1949), 情報理論の最重要な基礎量の一つである. (甘利, 1970)(Gray, 1990)(韓, 小林, 1999)(高

No.16-00497 [DOI:10.1299/transjsme.16-00497], J-STAGE Advance Publication date: 26 December, 2016

*1 正員, 徳島大学大学院 理工学研究部 ( $770-8506$ 徳島県徳島市南常三島町 2-1)

*2 正員, 名誉員, 名古屋大学名誉教授（广464-8601 愛知県名古屋市千種区不老町）

E-mail of corresponding author: ichimiya @tokushima-u.ac.jp 
岡, 2012)

本研究は主にこのシャノンエントロピーと後述の順列エントロピーや Kullback-Leibler のダイバージェンスを 用いて混合層の遷移過程を解析寸るものであるが，これらのエントロピーを利用して流れ場を調べることはまだ 一般的ではないので, 関連した先行研究事例を以下に述べる.

シャノンエントロピーを乱流場に適用した最初は, 著者らの調べた範囲では, 1986 年のCorke と Guezennec(Corke and Guezennec, 1986)の研究である. 彼らは乱流境界層の秩序構造 (coherent structure, 以下コヒー レント構造と呼ぶ）を客観的に識別する方法として, 多本熱線センサーの時系列出力を, コヒーレント部分とラ ンダム部分に分解できるとした．そしてコヒーレント部分は，この時系列に付随するシャノンエントロピーの最 大化により定まるとし，それを変分法に於ける Lagrange の乗数法を用いて計算した. その結果は，粗いグラフで あるが VITA 法(Blackwelder and Kaplan, 1976)による結果とほぼ同様な抽出が出来たとしている.この方法は必要 とされるデータ量と計算量が大きく, 彼ら以降は用いられていないようである.

同じ頃，水理学に於いて開水路の乱流平均速度分布の決定に最大エントロピー法を用い， Lagrange の乗数法で それを解いた報告があり(Chiu，1987), Prandtl-Kármán の普遍対数速度分布よりも開水路の実験結果によく一致す るとしている．またこの速度分布は，かなり後にこれと全く異なる Lie 群の方法で導かれた Oberlack の速度分布 と類似の形であることは注目に值する(Oberlack, 2001)(Lindgren et al., 2004)(Tsuji et al., 2005). 開水路問題ではその 後, 広くこの方法が活用されている. なお流れの問題にシャノンエントロピーを用いることを提案した最初は, 環境・土木工学の分野で, 水文学的流域自然景観の変化問題に適用されている(Leopold and Langbein, 1962). この 方面では，最近の展望(Singh, 2011)や著書(Singh, 2013)を参照されたい.

乱流に関してはIkeda と Matsumoto (Ikeda and Matsumoto, 1989)が一様乱流の波数空間に於いて $n$-step Shannon entropy を適用して高次元カオスを調べることを提案しているが, 実際の計算はカオス解を持つ既知の方程式計算 結果を調べるにとどまっている．海洋密度逆転成層流中には混合パッチ（mixing patch）と呼ばれる空間スケール が数メートルから数十メートルの乱流塊が点在し, この海水密度変動の測定結果の分析にシャノンエントロピー が用いられている(Wijeskera and Dillon, 1997). 彼らは海洋測定データの分析に先立って Dimotakis ら(Dimotakis et al., 1983)の印刷されたジェットの可視化写真をスキャンし，その結果にシャノンエントロピーを適用し，下流に 向かってそれが増すことを示している. ただし, 写真の光強度バーを基にジェット断面全体に亘る光の強度コン ターを算出し, その数值分布のシャンノンエントロピーを計算したもので, 各位置での確率密度関数を用いたも のではない．この点に関しては後に触れる．このようにシャノンエントロピーが乱流に対して適用された例はあ るが，乱流遷移過程に適用された例は無い.

乱流に於いても情報理論に於いても重要な関数は確率密度関数（probability density function, 以下, Pope(Pope, 2000)に従ってPDF と書く）である. 乱流場に於いては変動速度各成分の各位置でのPDFが現れるので, それら の変化が重要である.PDFの変化の定量化（あるいはPDFの類似度の定量化）には各種の方法があるが，中でも Kullback-Leibler のダイバージェンス（以下，KL ダイバージェンスと呼ぶ. なお，この量にはいろいろな呼び方 があるので注意が必要である) が適切な距離的性質を持ち重要である(韓，小林，1999). 文献(Tsuji and Nakamura, 1999)では乱流境界層の内部の KL ダイバージェンスを求め 3 次元図を示して, 対数領域でこれがほぼ一定である ことを明らかにしている. また文献(Tsuji et al., 2005)では零圧力勾配下の PDF の相似性が調べられ，この存在が 示されている. これについては展望(Nakamura and Tsuji, 1995)を参照されたい. Cerbus と Goldburg はシャノンエ ントロピーを一般化してブロックエントロピーを提案し， 2 次元石鹸膜乱流を調べている(Cerbus and Goldburg, 2013). 彼らはまた, 同じ流れの空間的予測問題を扱うためにシャノンエントロピーの他に Cruchfield 複雑度 $C$ を 利用している(Cerbus and Goldburg, 2015). またこの 2 次元乱流場について Richardson カスケードの発達を条件付 エントロピーにより解析している(Cerbus and Goldburg, 2016). 文献(Buxton, 2015)では乱流混合層の数值シミュレ ーションデータの諸量の解析に KL ダイバージェンスが用いられ，大スケールの影響が解明されている．また， 乱流の情報のスケーリングにシャノンエントロピーが利用されている(Granero-Belinchon et al., 2016). このように KL ダイバージェンスが乱流遷移過程に適用された例は無い.

さらに最近, データの並びの複雑度を考慮する順列エントロピー (permutation entropy) が提案され(Bandt and Pompe, 2002), 各種の場合に適用が試みられている(Cao et al., 2004)(Rosso et al., 2007)(Zanin et al., 2012)(Riedl et al., 2013)(Li and Fu, 2014)(Weck et al., 2015). また力学系と順列エントロピーの関係が著書で論じられている(Amigó, 


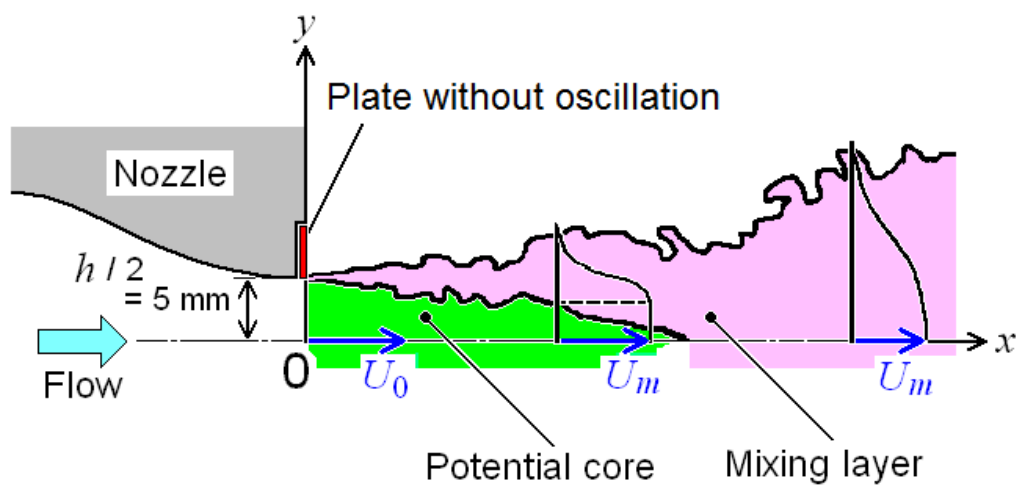

Fig. 1 Schematic diagram of two-dimensional mixing layer and coordinate system. The mixing layer is formed between the jet and the surrounding quiescent fluid.

2010). しかし，これを本研究のような乱流場や乱流遷移過程に適用した例は見当たらない. なお，情報理論と物 理現象との関連は早くから研究されており(Brillouin, 1956)，最近では文献(Jaynes, 2003)があることを注意する.

本研究は, 混合層遷移過程に関して, 上記のような各種のデータ解析手法を適用し, その特徵を比較して調べ, 遷移過程, 乱流データ解析への有効性を明らかにしようとするものである. また，乱流のシャノンエントロピー の方程式を乱流場の PDF 方程式から導いて, 乱流のシャノンエントロピーの物理的特性の理解も試みたものであ る.

\section{2. 実験装置及び実験方法}

解析した流れは，静止流体中に噴出寸る噴流の初期に形成される混合層である．噴流は幅 $310 \mathrm{~mm} ，$ 高さ $h=10$ $\mathrm{mm}$ の 2 次元ノズル出口（流れ方向座標 $x=0$ ） から噴出する. 図 1 に流れ場の上半分及び座標系を示す. 著者ら はこれまでこの流れの平均, 変動速度分布, 噴流の広がり, 摚乱の運動エネルギの生成率, 対流率及び散逸率の 下流への変化などを調べた(一宮他，2011a)(Ichimiya et al., 2011). また乱流遷移過程の垂直方向への進行を明らか にしたり, 佐藤の杂隹然度を求めて遷移進行への適用可能性を調べた(一宮他, 2011b)(Ichimiya et al., 2013a). またノ ズル出口に擋乱として取り付けた振動板の振幅や周波数の影響(一宮他，2013b)を調へ，振動板の振動様式の影響 (Ichimiya et al., 2014)を検討した.

本解析は，この流れのコルモゴロフ複雑度解析(一宮, 中村, 2012)(Ichimiya and Nakamura, 2013) と同様に, ノズ ル出口に上下一枚ずつ設置した振動板がノズル出口断面を狭めないように静止した場合のみを対象とした. 実験 は, 板を静止させたときのノズル出口直後の速度 $U_{0}$ とノズル出口高さ $h$ に基づくレイノルズ数を $5000\left(U_{0} \fallingdotseq 7.5\right.$ $\mathrm{m} / \mathrm{s}$ ）として行なった. 測定には各受感部直径 $5 \mu \mathrm{m}$, 長さ $1 \mathrm{~mm} の \mathrm{X}$ 型熱線プローブを用い, 風速に比例したそ の出力電圧はサンプリング周波数 $5 \mathrm{kHz}$ で 262144 個（約 52 秒間）サンプリングされた．そのデータから合成さ

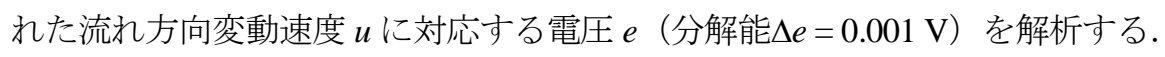

測定は垂直方向座標 $y \geqq 0$ の範囲で行った. 測定は, ポテンシャルコアが消滅して混合層の自己保存が成立す

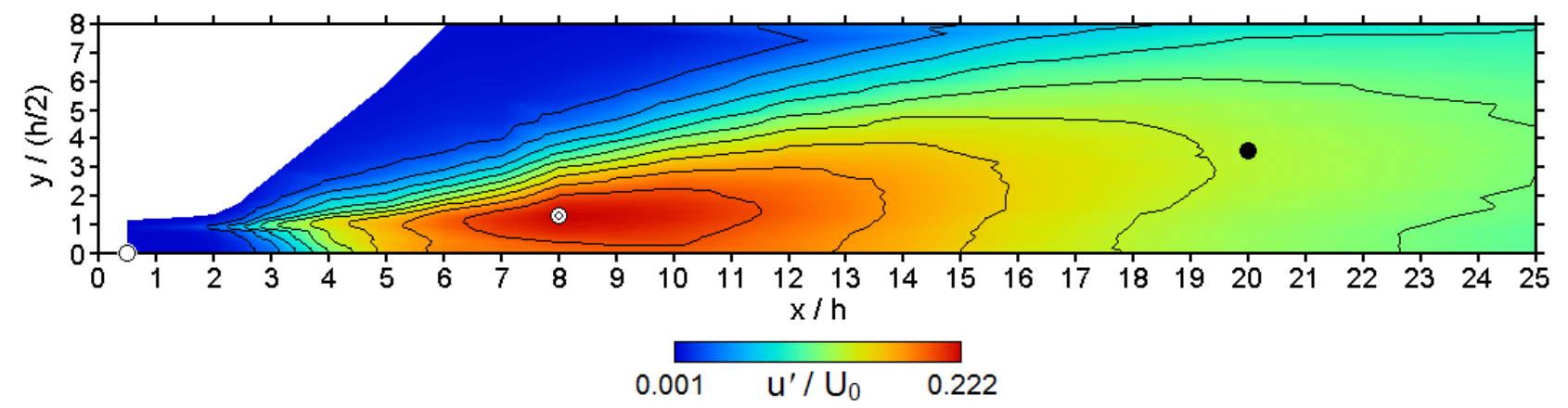

Fig. 2 Contour map of streamwise fluctuating velocity in $x-y$ plane. The root mean square value of the fluctuating velocity is normalized by the nozzle exit velocity. Three representative positions are shown by $\bigcirc$, $\bigcirc$ and $\bigcirc$ symbols. Nine contour lines are drawn with ten equal intervals between the maximum and minimum values. 
Table 1 Statistics at three representative positions.

\begin{tabular}{|c|c|c|c|l|l|l|l|l|}
\hline$x / h$ & $y /(h / 2)$ & Symbol & $u^{\prime} / U_{0}$ & $\begin{array}{l}\text { Integral } \\
\text { time, } T_{E} \\
{[\mathrm{~ms}]}\end{array}$ & $\begin{array}{l}\text { Taylor } \\
\text { micro time, } \\
\tau_{E}[\mathrm{~ms}]\end{array}$ & $\begin{array}{l}\text { Kolmogorov } \\
\text { time, } t_{K} \\
{[\mathrm{~ms}]}\end{array}$ & $\begin{array}{l}\text { Kolmogorov } \\
\text { length, } \eta_{K} \\
{[\mathrm{~mm}]}\end{array}$ & $\begin{array}{l}\text { Mean } \\
\text { velocity, } U \\
{[\mathrm{~m} / \mathrm{s}]}\end{array}$ \\
\hline 0.5 & 0 & $\bigcirc$ & 0.003 & 22.7 & 3.18 & 203 & 1.71 & 7.19 \\
\hline 8 & 1.3 & 0 & 0.222 & 1.18 & 1.28 & 0.67 & 0.10 & 5.14 \\
\hline 20 & 3.6 & 0 & 0.130 & 6.55 & 1.91 & 0.95 & 0.12 & 2.85 \\
\hline
\end{tabular}

る位置よりも十分下流の $x / h=25$ まで行った. この中で, ノズル出口直後の中心線上 $(x / h=0.5, y /(h / 2)=0)$, 流 れ方向時間平均速度からの変動速度の $\mathrm{rms}$ 值 $u^{\prime}$ が最大の位置 $x / h=8, y /(h / 2)=1.3$ と, 十分下流の $x / h=20, y /$ $(h / 2)=3.6$ の 3 位置を代表として示す. $u$ ’をノズ出口速度 $U_{0}$ で無次元化した值のコンタ（図 2) において，それ ら 3 位置をそれぞれ $\bigcirc$, ○, ○印で示す. 図 2 の等高線は, 最大值と最小值間を 10 等分した間隔で 9 本を引いた. $x / h=0.5, y /(h / 2)=0$ (○印) はポテンシャルコア内の層流である. $x / h=8, y /(h / 2)=1.3$ (@印) では優先(preferred) 周波数（渦合併の連続経過の最後に残る卓越周波数）が存在する. $x / h=20, y /(h / 2)=3.6$ (の印）では十分に乱 流遷移が完了している(一宮他，2011b) (Ichimiya et al., 2013a). また表 1 に，その 3 位置での諸量の值を示す.

\section{3. データ解析手法}

\section{$3 \cdot 1$ シャノンェントロピー}

乱流場は連続的に変化する量から成り立つので, Shannon の連続量のエントロピーが現れるが，実験に於いて も CFDに於いても実際に取り扱える量は離散数值である. そこで, 熱線風速計出力がサンプリングされ， A/D 変 換されたデータを離散確率変数として調べることにする. 前述の文献(Corke and Guezennec, 1986)に於いても熱線 出力を離散化して，離散量として扱っている。なお，情報論的に見た場合の離散量と連続量の差異は，提案者の Shannon が詳細に論じているので文献(Shannon and Weaver, 1949)を参照されたい.

ある離散確率空間上の確率分布 $P$ が与えられたとき, $n$ 個存在する各事象 $X_{i}$ の確率は, $p_{i}=P\left(X_{i}\right)$ あ゙あり, $X_{i}$ の 自己情報量は一 $\log P\left(X_{i}\right)=-\log p_{i}$ と定義され, $\left\{p_{i}: i=1,2, \cdots, n\right\}$ のシャノンエントロピーは, 自己情報量の期待 值として次式で定義される.

$$
-\sum_{i=1}^{n} p_{i} \log p_{i}
$$

対数の底は通常 2 とすることが多く, この場合は単位[bit]を用いる. また $p_{i}=0$ のときは $p_{i} \log p_{i}=0$ と定義する. このシャンノンエントロピーを計算するに於いて，まず $p_{i}$ を決定する必要があるが，この方法はある区間に速度 信号が含まれる時間割合を求める通常の方法によって求めた

ここで, 確率分布を含む一般の 1 価有界関数 $y=F(x)$ のグラフを統計学でいう離散棒グラフで表現し分類するこ とを考えてみる. 有限個の点, $x_{1}<x_{2}<\cdots<x_{n}$ に対して $F_{i}=F\left(x_{i}\right)$ と置けば，有限離散数值集合が得られる. ただし，簡単のため， $F(x) \geqq 0$ とする. $\sum F_{i}=M$ とし,$f_{i}=F_{i} / M$ ととると，

$$
f_{i} \geqq 0, \quad \sum f_{i}=1
$$

なる性質の離散数值集合 $\left\{f_{1}, f_{2}, \cdots, f_{n}\right\}$ が得られる。これを $1,2, \cdots$ の順序で棒グラフに描けば $F(x)$ のグラフの正規 化した棒グラフ表現となる. 単なる集合では要素の並びは意味を持たないが，ここでは要素 $f_{i}$ の並びの順序が意 味を持つので離散時系列と考えられる，すなわち $\left\{f_{i}\right\}$ は連続データ $F(x)$ のサンプリング值集合（通常， $x_{i}$ は等間 
隔にとられる）を正規化したものである．上記の性質から， $H=-\Sigma f_{i} \log f_{i}$ が定められ， $H$ はこの棒グラフの分 布形状, 従って元の関数 $F(x)$ の形状を代表する一つの指標と考えることが出来る. $H$ 以外に通常の 1 次, 2 次モ 一メントがあるのはむろんである，Hがモーメントとは異なる指標である理由の一つは， $f_{i}=1 / n$ の等値集合の時 に $H$ が最大となることである．これらは，Shannon が確率分布を想定して導入したエントロピーが，確率とは直 接には関係しない一般のグラフの特性量にもなることを意味する．ただし，上のように定めた集合 $\left\{f_{i}\right\}$ は確率論 の公理を満たすので，何らかの事象の確率ともいえるが $\left\{f_{i}\right\}$ みでは何の事象の確率かは不明である。このよう な $H$ を最初に考え提案したのが，前述の Wijeskera と Dillon(Wijeskera and Dillon, 1997)である. 彼らはこの量をス ペクトルの topological measure と呼んでいるが，この”topological”は単純に形状を意味している．なお，上に与え たような説明は彼らの論文にはない. また, $H$ では要素の順序の意味は失われる. 次にこの方法に着目したのは,

著者らの調べた範囲では, Wesson ら(Wesson et al., 2003)で. 彼らは大気中の乱流エディ（“渦”には 1 回転する旋 回と言う語感が非常に強いので，ここではエディと呼ぶことにする）の分析のため, 大気中鉛直速度分布の非線 型時系列解析の一つとして上記のような, その分布の棒グラフ表現を離散エントロピーで解析し, 流れの安定性 に基づく組織化と粗さによるものとの分離に使っている. しかし，これらの論文では本研究のような乱流場の各 点でのシャノンエントロピーは求められていない.

さて本研究におけるシャノンエントロピーは, 前述のように流れ方向変動速度に比例した電圧 $e$ に対して確率 を計算して求める. 確率の計算に当り, 電圧の 1 区間の幅を決定する必要がある. 区間幅が狭くなれば式(1)にお ける区間数 $n$ が増加し，一般に区間数が増加すればシャノンエントロピーは増加するからである．そこで図 2 に 示した 3 位置において区間数に対するシャノンエントロピーの変化を調べた. 262144 個のデータの值の範囲（デ 一タ中の最大值 $e_{\max }$ と最小值 $e_{\text {min }}$ の差 $)$ を 2 のべき乗の 13 通りの分割数 $\left(16\left(=2^{4}\right) \sim 65536\left(=2^{16}\right)\right.$ ) で等分割し たシャノンエントロピーの変化を図 3 に示す. 初めは区間数の増加と共にシャノンエントロピーは増加する. 3 位置の $\left(e_{\max }-e_{\min }\right) / \Delta e$ の值に縦破線を引いたが，区間数がこれを越えるとシャノンエントロピーは一定值に飽和 寸る. これは分解能以上に区間が細分化されて増えても，その区間内にはデータが存在しないから $p_{i} \log p_{i}=0$ と なってシャノンエントロピーに寄与しないからである，そこで，シャノンエントロピーにはその飽和值を採用寸 ることにした.

\section{$3 \cdot 2$ 順列エントロピー}

シャノンエントロピーでは考慮されていないデータの順序に基づく大小関係を考慮したものが順列エントロピ 一である.これは Bandt と Pompe(Bandt and Pompe, 2002)が提案したデータ解析法である. 要素 $T$ 個の時系列 $\left(x_{1}, x_{2}\right.$, $\left.\cdots, x_{T}\right)$ から要素 $n$ 個の数列 $\left(x_{t+1}, x_{t+2}, \cdots, x_{t+n}\right)$ を, $0 \leqq t \leqq(T-n)$ に亘って $T-n+1$ 回取り出すとき, $n$ 個要素内に相等し い值がまったくなければ, 大小関係の事象 (順列) の数は $n$ ! である. このとき各順列の確率 $p_{i}$ は, $(0 \leqq t \leqq(T-n)$ の範囲内での, その順列の個数) / $(T-n+1)$ となるので, そのエントロピー (順列エントロピー) $H_{p}$ がシャノン エントロピーと同様に,

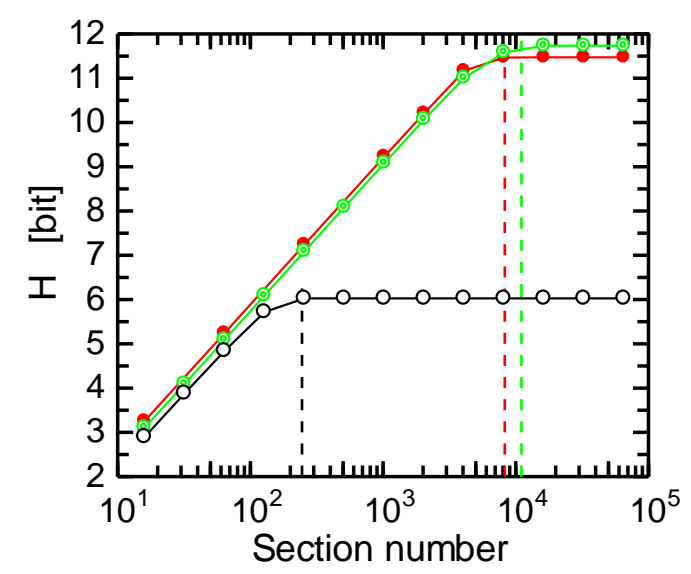

Fig. 3 Shannon entropy as a function of section number. $\bigcirc$, black, $x / h=0.5, y /(h / 2)=0$; $\bigcirc$, green, $x / h=8, y /(h / 2)=1.3$; $\bigcirc$, red, $x / h=20, y /(h / 2)=3.6$. Vertical broken lines indicate values of $\left(e_{\max }-e_{\min }\right) / \Delta e$ of respective positions. Shannon entropies increase first, then become constant. 


$$
H_{p}=-\sum^{n !} p_{i} \log p_{i}
$$

で定義される．順列エントロピーを， $n-1$ または $\log n$ !で正規化することもある.

順列エントロピーを求めるに当り，決定するべきパラメーターや事項は大きく 3 つある.まず $n$ 個の要素内に 相等しい值が複数あるときの取り扱いであるが，白色雑音を等しい值に加えて異なる值にする方法が提案されて いる(Riedl et al., 2013)(Li and Fu, 2014). この場合, 加える值には何も作為がないので, データ数 $n$ が多数であれば, 人工的に生じた大小関係は平均化 (平坦化) されるであろう。しかし層流のように元々変化が少ないデータでは, あえて大小関係を付加するよりも，值が変化しない事実も反映させるべきと考え，要素内に等しいものがあると いう事象も順列に含めることにし，白色雑音は加えなかった。 ゆえに順列数は前述の相等しい值がまったくない 場合の $n$ !よりも多くなり得る.

次に，取り出す数列の要素数 $n$ の選択であるが， $n$ が少なければ順列の種類が少なくなるので，データの変化 を十分に反映できない. しかし $n$ が多すぎると取り出せる数列の数 $(T-n+1)$ が少なくなる. 図 4 に元の時系列 の要素数 $T$ を熱線風速計データサンプリング総数の 262144 に等しくとり $n$ を変化させた時の順列エントロピー の変化を示す. 図 $4(a)$ の有次元順列エントロピーが $n$ と共に増加するのは, 順列数が増加するからである. この ため順列数の変化を図 5 に示す. 順列数は初めは $n$ と共に増加している. 要素数 $T$ は 262144 という大きい数な ので， 3 位置とも $n=2$ では，取り得る順列最大数（=3）になっているが， $n=3$ になると差が出てくる. $n$ がさ らに増えると順列数は一定に飽和する。これは取り出す熱線風速計時系列信号のデータ数 $n$ が十分に長くなると （長さはおそらく Taylorの積分スケールのオーダ）その中に現れるパターンの種類が有限になることを意味する と思われる．本研究では図 4(b)の $n-1$ で正規化した順列エントロピーが最大に近い $n=8$ (図 4, 5 中の縦破線位 置) を採用する。これは文献(Riedl et al., 2013)で調べられている值 2〜10 に入っている.

最後に元の時系列の要素数 $T$ の選択である. $n=8$ とした時の, 順列エントロピーと順列数の $T$ に対する変化
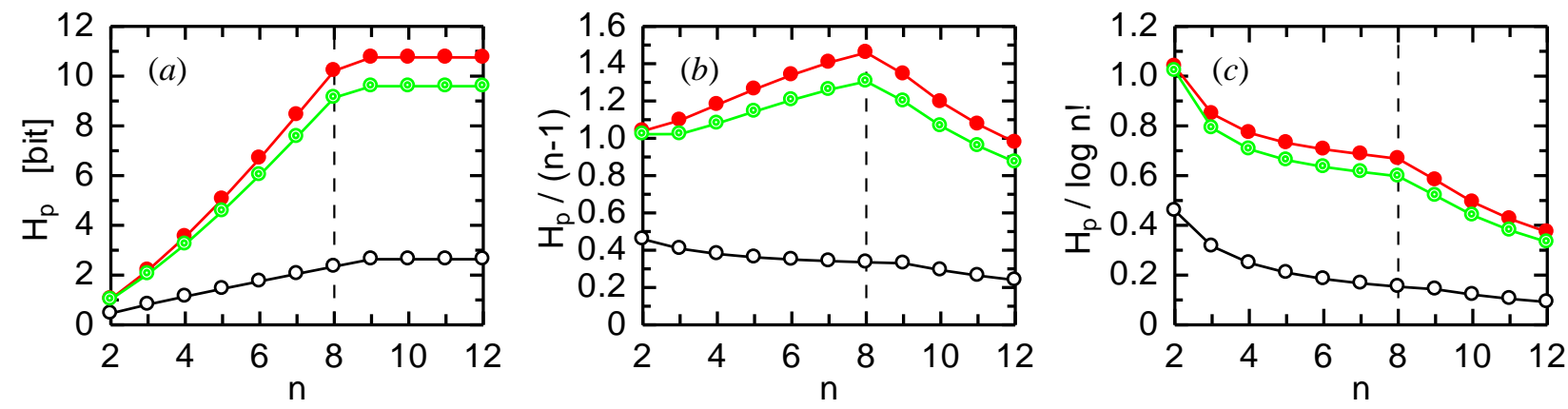

Fig. 4 Permutation entropy as a function of data number. (a) dimensional; $(b)$ normalized by $n-1$; $(c)$ normalized by $\log n$ !; $\bigcirc$, black, $x / h=0.5, y /(h / 2)=0$; $\bigcirc$, green, $x / h=8, y /(h / 2)=1.3 ; \bigcirc$, red, $x / h=20, y /(h / 2)=3.6$. The dimensional permutation entropy increases first because of the increase of the permutation number, then becomes constant when the data number increases sufficiently.

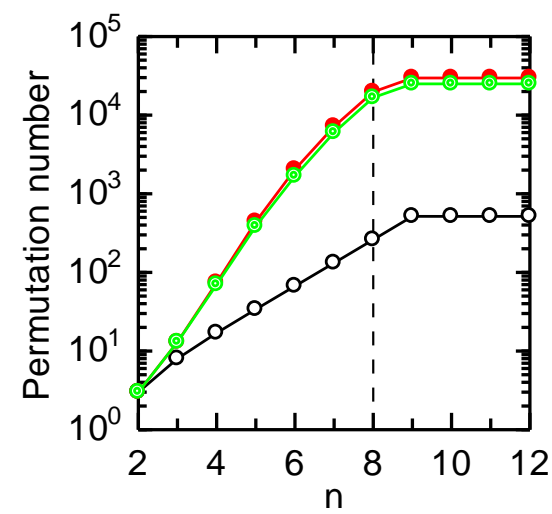

Fig. 5 Permutation number as a function of data number. $\bigcirc$, black, $x / h=0.5, y /(h / 2)=0$; $\bigcirc$, green, $x / h=8, y /(h / 2)=1.3$; red, $x / h=20, y /(h / 2)=3$.6. Permutation number increases first, then it becomes constant when the data number increases sufficiently. This means that the pattern variation within sufficiently long hot-wire output data is definite. 

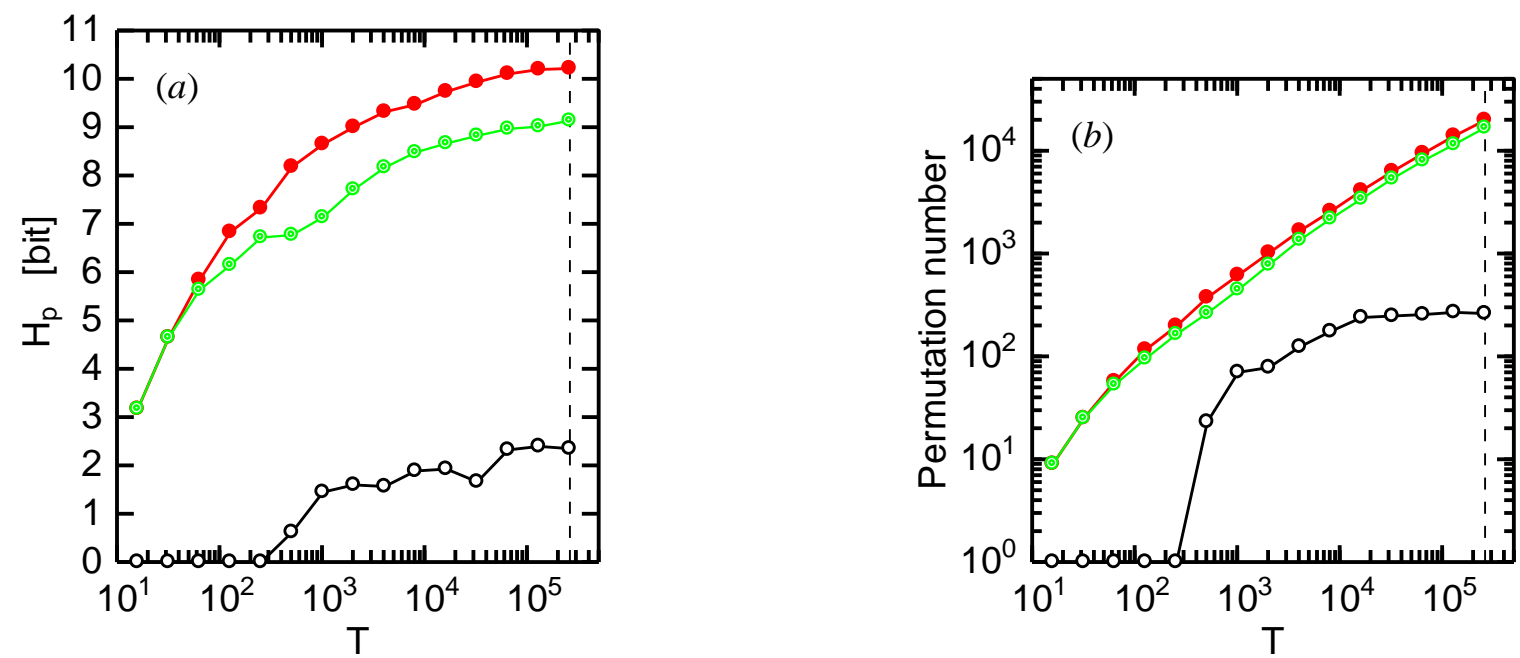

Fig. 6 (a) Permutation entropy and $(b)$ permutation number as a function of base data number. $n=8$. $\bigcirc$, black, $x / h=0.5, y /(h / 2)$ $=0$; $\bigcirc$, green, $x / h=8, y /(h / 2)=1.3 ; 0$, red, $x / h=20, y /(h / 2)=3.6$. Both increase with the base data number.

を図 6(a), (b)にそれぞれ示す．層流の $x / h=0.5, y /(h / 2)=0$ (O印) において $T$ が小さいうちは順列数が 1 である のは, $n=8$ 個のデータがすべて等しいからである. 順列エントロピーも順列数も $T$ と共に単調に増加しているの で，Tはサンプリング総数の 262144（図 6 中の縦破線位置）を採用する.

また，特に層流においては，信号中に存在寸る高周波ノイズのために值の差異が生じるので，この高周波ノイ ズを除去するために，原データにそのデータの変動速度 $\mathrm{rms}$ 值 $u$ 'を乗じることにより，u’゙小さい層流では変動 がデータの分解能以下に減衰するようにさせた，具体的には，前述の変動最大位置 $x / h=8, y /(h / 2)=1.3$ では局

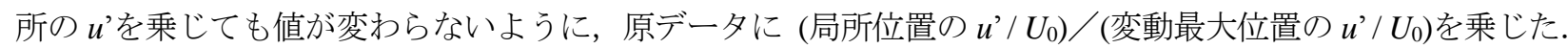

\section{$3 \cdot 3 \mathrm{KL}$ ダイバージェンス}

$\mathrm{KL}$ ダイバージェンスは $2 つ の$ 確率変数の密度関数 $P(x)$ と $Q(x)$ の形状の差異を定量的に表示する指標であり(韓, 小林, 1999), 次式で与えられる.

$$
D=\int P(x) \log \frac{P(x)}{Q(x)} d x
$$

ここで $0 \log (0 / a)=0(a \geqq 0)$ と約束する. 本研究では 2 つの位置 $X, Y$ における流れ方向変動速度 $u / U_{0}$ の PDF である $P_{X}\left(u / U_{0}\right)$ と $P_{Y}\left(u / U_{0}\right)$ の分布形状の差異を表すために, KL ダイバージェンスを次式のように求めた.

$$
D=\sum P_{X}\left(u / U_{0}\right) \ln \frac{P_{X}\left(u / U_{0}\right)}{P_{Y}\left(u / U_{0}\right)} \Delta\left(u / U_{0}\right)
$$

基準位置 $X$ は，過去に行なったコルモゴロフ複雑度解析(一宮，中村，2012)(Ichimiya and Nakamura, 2013)と同 様に，ノズル出口直後の中心線上 $(x / h=0.5, y /(h / 2)=0)$ とした. PDF はすべて- $1 \leqq u / U_{0} \leqq 1$ の範囲を 400 分割, すなわち $\Delta\left(u / U_{0}\right)=0.005$ として求めた.

\section{4. 解析結果及び考察}

\section{$4 \cdot 1$ シャノンエントロピー}

シャノンエントロピーの $x-y$ 平面上のコンターマップを図 7 に示寸. $x / h \leqq 3$ ではノズル外端の $y /(h / 2)=1$ 付 近で最大である. これよりも内側（ $y /(h / 2)$ の小さい側）にはポテンシャルコアがあるために小さい. すなわち層 
流では小さい，ポテンシャルコアが消滅すると，中心線（ $y=0)$ を含むある程度 $y /(h / 2)$ の広い範囲でシャノンエ ントロピーは大きい.

中心線 $y=0$ 上 (O印), 及び各 $x$ における変動速度 $\mathrm{rms}$ 值 $u^{\prime}$ の $y$ 方向分布において最大となる位置（印）に おけるシャノンエントロピーの $x$ 方向変化を図 $8(a)$ に示寸. どちらも $x / h=4$ まで単調増加して, 以後はほぼ一定 となる. ゆえにシャノンエントロピーは混合層の乱流遷移進行の測度としても有効と考えられる. 佐藤が提案し た雑然度は単調に変化しなかったが(一宮他, 2011b)(Ichimiya et al., 2013a), このシャノンエントロピーは単調に増 加して最大になった後もあまり減少しない。これはコルモゴロフ複雑度解析における近似コルモゴロフ複雑度 AK(一宮，中村，2012)(Ichimiya and Nakamura, 2013) とも異なり，コルモゴロフ複雑度解析における正規化圧縮距 離 NCD と同様の優れた性質である. ただし NCD と同様に, 乱流遷移が完成する $x / h=10 \sim 14($ 一宮他, 2011b)(Ichimiya et al., 2013a)よりもかなり上流で最大になる.

代表的な 5 つの $x$ におけるシャノンエントロピーの $y$ 方向変化図 8(b)に示す. $y /(h / 2)$ が増加するとシャノンエン トロピーは減少する. $x / h=3$ の分布は特徵的である. 図 7 のコンター図の対応位置と比較すると, ノズル外端 $(y /(h / 2)=1)$ 付近でシャノンエントロピーが最大となっており，これは遷移がこの付近から始まることを示すと 考えられる.

ここで，シャノンエントロピーが層流で小さく，乱流で大きくなる理由を確率分布から考察する．図 2 に示し た 3 位置のうち層流の $x / h=0.5, y /(h / 2)=0(H=6.0269)$ と乱流の $x / h=8, y /(h / 2)=1.3(H=11.734)$ において考 察する. 図 9 に両位置の確率分布を示寸. 横軸は変動電圧を有次元值で示す. 層流 $(a)$ ではデータ点を○印で示し て直線で結ぶが，乱流 $(b)$ ではデータ点を省いて直線のみを描いた．いずれも 0 である確率が見られるが，これは 前述のように，分解能以上に区間が細分化されているのでデータが存在しない区間があるためである. なおそこ では $p_{i} \log p_{i}=0$ となるから，これも前述のようにシャノンエントロピーには寄与しない.

さて, 図 9 からわかるように, 層流では変動電圧の範囲が狭く, 等しい值を取る頻度が多いので, 前述の離散 棒グラフのいわば棒が少なく, 確率（各棒の高さ）は大きい.このためシャノンエントロピーは小さくなる.こ れに対して乱流では変動電圧の範囲が広いので, 前述の離散棒グラフのいわば棒が多い（図 9(b)においては多数 の棒が密集している).このためシャノンエントロピーは大きくなる. 結局, 層流と乱流間の速度変動の大きさの

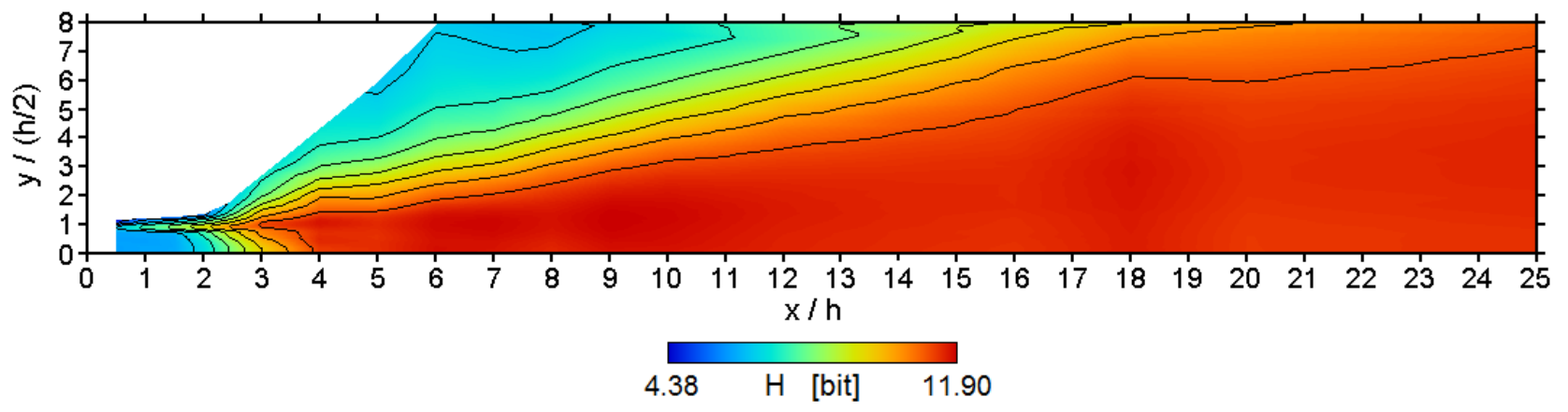

Fig. 7 Contour map of Shannon entropy in $x-y$ plane. Nine contour lines are drawn with ten equal intervals between the maximum and minimum values. Shannon entropy is low in the laminar region and high in the turbulent region.
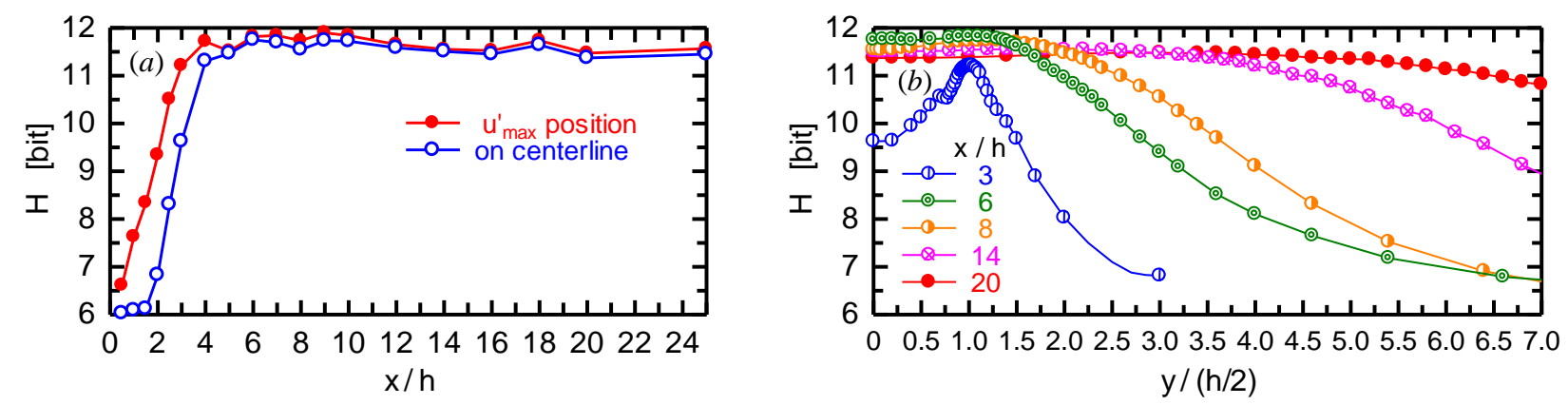

Fig. 8 Shannon entropy as a function of $(a)$ streamwise distance, and $(b)$ flow-normal distance. In the streamwise variation, the Shannon entropy first increases, then becomes constant. Therefore, the Shannon entropy can be a measure of the transition process. In the flow-normal variation, it decreases as the flow-normal distance except for $x / h=3$. 

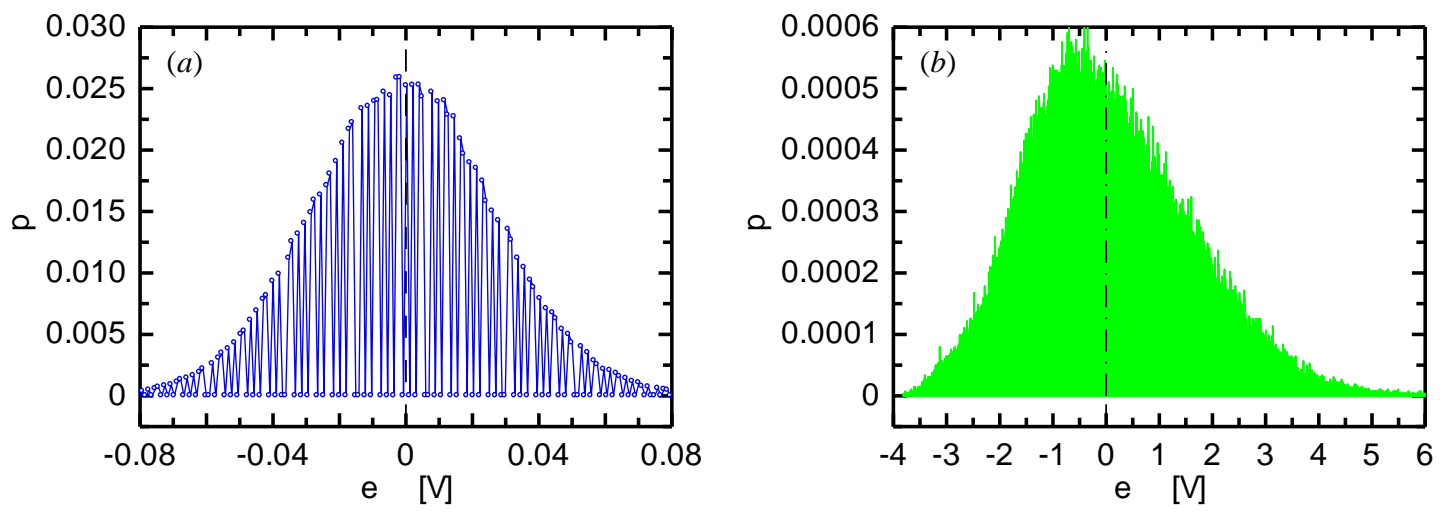

Fig. 9 Probability distribution of fluctuating velocity at $(a) x / h=0.5, y /(h / 2)=0,(b) x / h=8, y /(h / 2)=1.3$. In the laminar region, $(a)$, the probability distributes in a narrow range of the fluctuating velocity, and thus the Shannon entropy becomes small. On the other hand, in the turbulent region, $(b)$, the probability distributes in a wide range of the fluctuating velocity, and thus the Shannon entropy becomes large.

差異がシャノンエントロピーの值に寄与する．ただし，正規化すると層流ではシャンノンエントロピー最大のガ ウス分布(Shannon, 1948)に近い形状であり，乱流では歪んでいる．このように速度変動の大きさの変化が正弦波 の振幅変化のようなものではなく，複雑度の増大にも起因していることが，シャノンエントロピーにより解明で きた.

\section{$4 \cdot 2$ 順列エントロピー}

順列エントロピーのコンターを図 10 に示す．また，中心線 $y=0$ 上 (O印)，及び各 $x$ における変動速度 $\mathrm{rms}$ 值 $u^{\prime}$ の $y$ 方向分布において最大となる位置

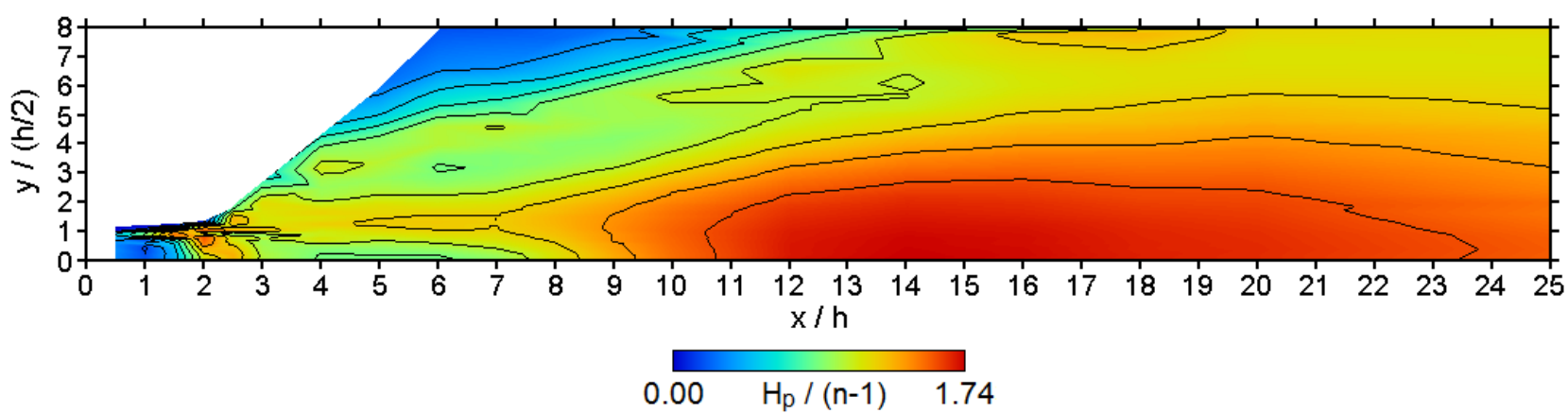

Fig. 10 Contour map of permutation entropy in $x-y$ plane. Nine contour lines are drawn with ten equal intervals between the maximum and minimum values. The distribution of the permutation entropy is more complex than that of the Shannon entropy.
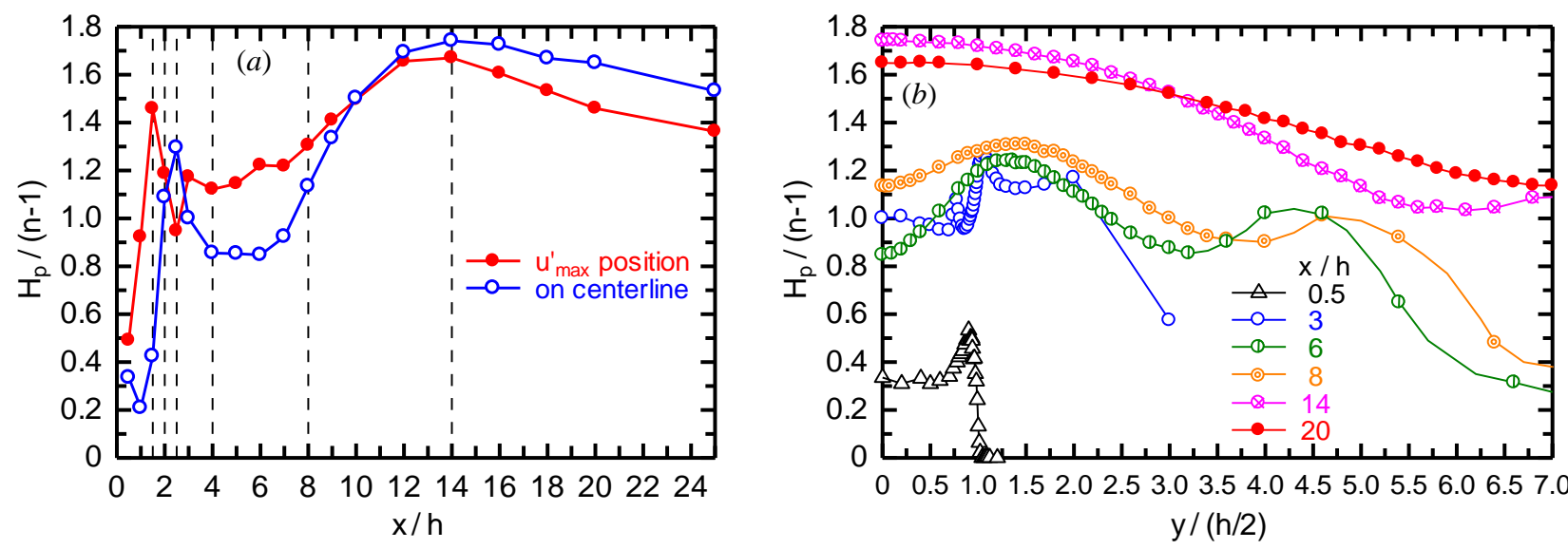

Fig. 11 Permutation entropy as a function of $(a)$ streamwise distance, and $(b)$ flow-normal distance. In the transition process, the permutation entropy increases first, then decreases and increases again in the streamwise direction. It finally decreases downstream. 
化を図 11(a)，(b)にそれぞれ示す。

順列エントロピーのコンター（図 10）はシャノンエントロピーのそれ（図 7）に大略似ているが，明確に異な るところがある. 図 10 では $3<x / h<8$ において順列エントロピーの低い領域が高い領域に挟まれて長く伸びてい る部分が目立つ.この部分は秩序的乱流エディに対応するのであろう.

順列エントロピーはシャノンエントロピーとは異なって複雑に変化するので，ここからはこの変化について詳 しく考察する. 例えば図 11(a)の $x$ 方向変化においては, どちらの位置 $y$ でも, まずノズル直後では小さい值で, 次にいったん増加して極大となった後に減少し, 再び増加するが最終的には再び減少する. 2 つの yでの分布は, 互いに前後（ $x$ 方向）に多少シフトしているだけなので，代表として中心線上（O印）の変化を考察する.

$x$ 方向断面の代表として, ノズル直後の小さい值の位置 $(x / h=1.5)$, 少し増加した位置 $(x / h=2.0)$, 極大位置 $(x / h=2.5)$, , いったん減少して極小になる位置 $(x / h=4)$, 再び増加して $x / h=2.5$ の極大值と同程度になる位置 $(x / h$ $=8)$, 及び最大位置（ $x / h=14 ）$ の 6 断面を選び，特徵の変化とその理由を考察する. 図として変動速度波形（図 12. 横軸はデータ 200 個（時間 0.04 秒）分で， 1 刻みが取り出した数列のデータ数 $n=8$ に等しい. 縦軸は速度 に比例した熱線出力電圧である.), 変動速度パワースペクトル（図 13. 変動速度の分散で除している，全デー 夕（262144 個）内の 2 つの值のうち, 時刻が後の方の值が早い方よりも増加（速度変化率 $\Delta u / \Delta t$ が正）または減 少 $(\Delta u / \Delta t$ が負) または等しい $(\Delta u / \Delta t$ が 0) ものの比率 (図 14), 選び出した $n=8$ 個の数列が完全に単調増加（数 列内の 7 個の $\Delta u / \Delta t$ がすべて正）または単調減少（すべて負）する比率（図 15）を描く. 図 11(a)，14 及び 15 に は 6 断面の $x / h$ に縦線を引く.

まずノズル直後の $x / h=1.5$ では，変動速度波形（図 $12(a) ）$ から分かるように速度変動が小さい. ゆえに図 14
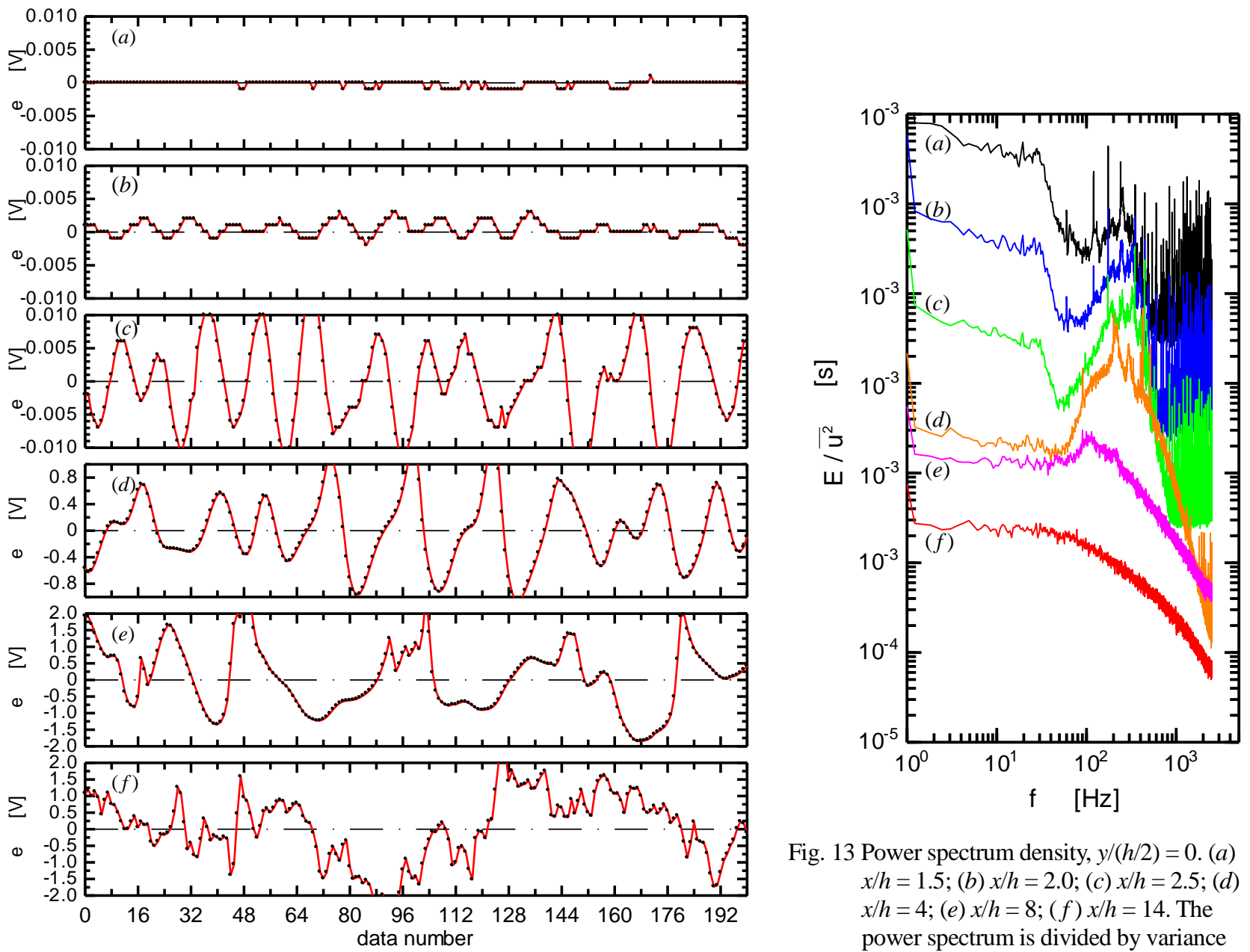

Fig. 13 Power spectrum density, $y /(h / 2)=0 .(a)$ $x / h=1.5 ;(b) x / h=2.0 ;(c) x / h=2.5 ;(d)$ $x / h=4 ;(e) x / h=8 ;(f) x / h=14$. The power spectrum is divided by variance of the fluctuating velocity. Therefore, the area under the spectrum curve becomes unity.

$=2.5 ;(d) x / h=4 ;(e) x / h=8 ;(f) x / h=14$. The axis of the abscissa is 200 of the data number. The range corresponds to $0.04 \mathrm{~s}$ of time. Note that the ordinate scale is expanded according to the fluctuating velocity. 


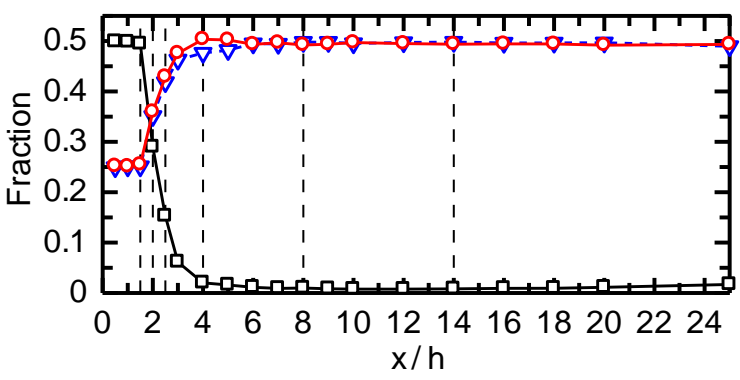

Fig. 14 Fraction of positive $(\bigcirc$, red), negative $(\nabla$, blue $)$ or zero ( $\square$, black) of $\Delta u / \Delta t$ within one permutation, $y /(h / 2)=0$. First, in the laminar region, the fluctuating velocity is low, therefore, the fraction of zero is larger than that of positive and negative. As the transition proceeds, the fraction of positive and negative increases.

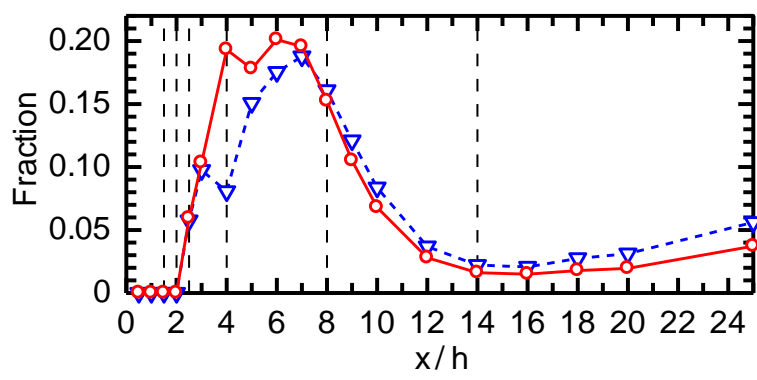

Fig. 15 Fraction of monotonic increase $(\bigcirc$, red $)$ or decrease $(\nabla$, blue) within one permutation, $y /(h / 2)=0$. With the growth of the fluctuating velocity, the monotonic change becomes dominant. As the irregular fluctuation becomes dominant, the monotonic change becomes less important.

において $\Delta u / \Delta t$ の正（○印，26\%）や負（ $\nabla$ 印，25\%）が少なく，0（ $\square$ 印，49\%）が多い。このため変化パター ンの種類すなわち順列数が少なく順列エントロピーは小さい.

順列エントロピーが少し増加した $x / h=2.0$ になると, 変動速度波形 (図 12(b)) から分かるように速度変動が増

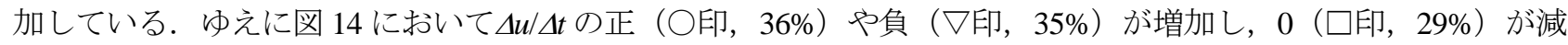
少した.このため変化パターン種類すなわち順列数は増加して順列エントロピーは増加した.

極大位置 $x / h=2.5$ になると, 引き続き速度変動の増加により, 図 14 において $\Delta u / \Delta t$ の正 $(\bigcirc$ 印, $43 \%)$ や負 $(\nabla$ 印，42\%）が増加し，0（口印，15\%）が減少する．ただしこれは変化パターン種類の減少に寄与する．その代わ り，変動が極めて大きな值にまでは達していないので， $\Delta u / \Delta t$ の正や負の傾向は長続きしない. このことは図 15 の $n=8$ 個の数列が完全に単調増加（○印）するのは $5.9 \%$, 単調減少（ $\nabla$ 印）するのは $5.8 \%$ すううさい值であ ることに反映している. これが寄与して，変化パターン種類すなわち順列数はさらに増加して順列エントロピー は増加した. この変化パターンは, 乱流場で表現すれば可視化などで見られる乱流エディのパターンを意味し, その増加はカスケード過程の進行を意味すると解釈できよう.

いったん減少して極小位置 $x / h=4$ になると,引き続き変動の増加により, 図 14 において $\Delta u / \Delta t$ の正 (O印, $50 \%)$

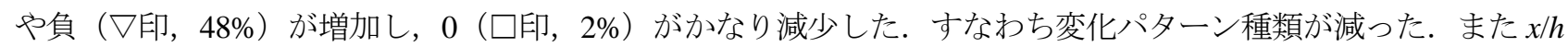
$=2.5$ よりも変動が増加したので， $\Delta u / \Delta t$ の正や負傾向は長続きする（図 15 の単調増加（○印）は $19.3 \%$, 単調減 少 ( $\nabla$ 印) は 8.1\%にまで増加している).これもパターン種類の減少に寄与する. また図 13(d)のパワースペクト ルからもわかるように，支配的な周波数の数（スペクトル分布中のピークの数）が減少し， $200 \mathrm{~Hz}$ や $300 \mathrm{~Hz}$ の一 定周期変動が支配することも, 変化パターン種類の減少に寄与寸る. 結局, これら 3 要因が相乗して変化パター ン種類すなわち順列数は減少して順列エントロピーは減少した.

再び増加して極大值と同程度の $x / h=8$ になると，図 14 からわかるように, $\Delta u / \Delta t$ の正 ( $\bigcirc$ 印), 負 ( $\nabla$ 印)， 0 ( $\square$ 印) は $x / h=4$ とほぼ変わらず, 正や負傾向の長続きも $x / h=4$ と変わらない(図 15 の単調増加 (○印) は $15.2 \%$,

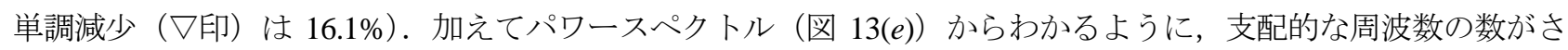
らに減少して優先周波数 $(100 \mathrm{~Hz}$ 強）だけになり, これは $x / h=4$ と同様に変化パターン種類すなわち順列数の減 少に寄与寸る. しかし変動速度波形図 12 から分かるように不規則変動が出現する. これが変化パターン種類の増 加に寄与して順列エントロピーは増加した.

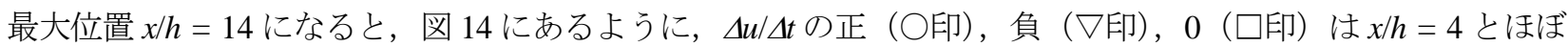
等しい．何よりも変動速度波形（図 12(f)）から分かるように不規則変動が支配的になる. このため $\Delta u / \Delta t$ の正や

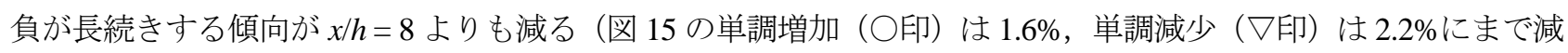
少)。これが変化パターン種類すなわち順列数の増加に寄与して順列エントロピーは増加した.

なお， $x / h=14$ を過ぎると順列エントロピーは下流方向に減少するが，これは図 15 に表われているように，単 調増加や減少の比率が増えるためである。

以上をまとめると, 混合層の自然遷移過程における変動速度の増加や, 周期変動から不規則変動への様式の変 化を，順列エントロピーは忠実に反映する. 


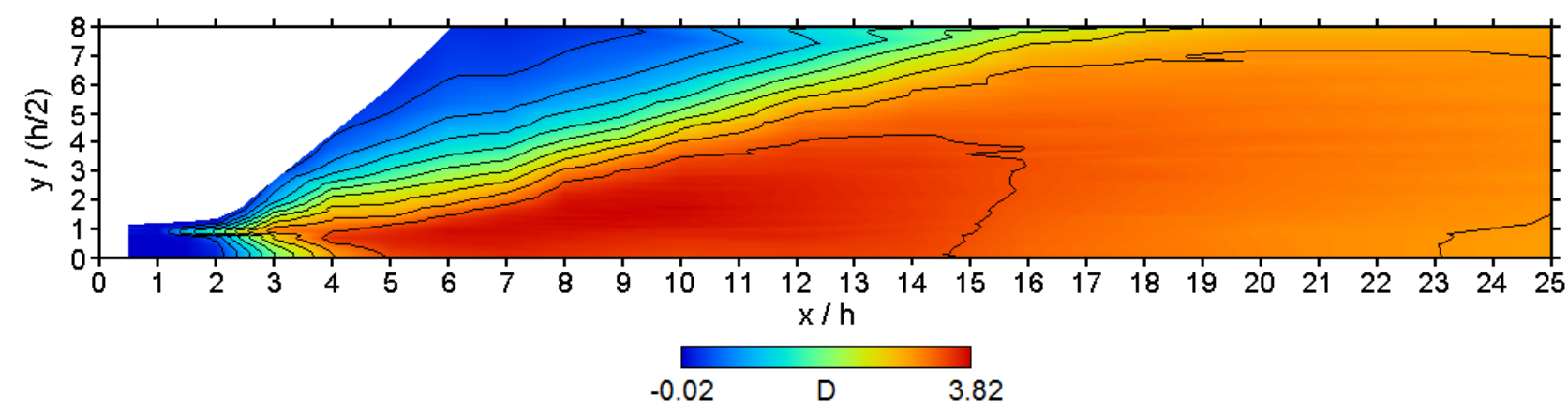

Fig. 16 Contour map of Kullback-Leibler divergence in $x-y$ plane. Nine contour lines are drawn with ten equal intervals between the maximum and minimum values. With the Shannon entropy, the $\mathrm{K}-\mathrm{L}$ divergence is low in the laminar region, and high in the turbulent region.
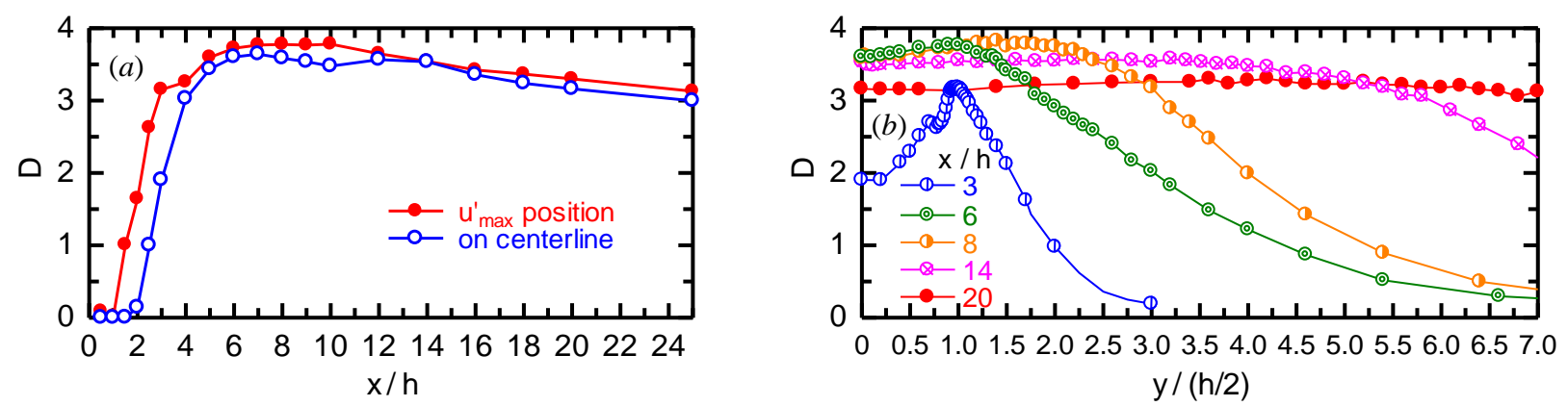

Fig. 17 Kullback-Leibler divergence as a function of $(a)$ streamwise distance, and $(b)$ flow-normal distance. In the transition process, the $\mathrm{K}-\mathrm{L}$ divergence increases first, then slightly decreases downstream.

\section{4・3 KL ダイバージェンス}

$\mathrm{KL}$ ダイバージェンス $D$ のコンターを図 16 に示寸. 図 16 中の $x / h$ や $y /(h / 2)$ における值が, その位置の $u$ の PDF を式(5)の $P_{Y}\left(u / U_{0}\right)$ とした $D$ である. 図 7 のシャノンエントロピーと同様に, ノズル直後の層流では值は小さく, 乱流遷移の進行と共に増加している。

KL ダイバージェンスの, 中心線 $y=0$ 上 (O印), 及び各 $x$ における変動速度 $\mathrm{rms}$ 值 $u$ 'の $y$ 方向分布において

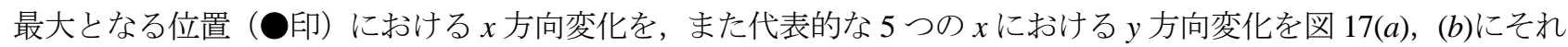
ぞれ示す. 図 $17(a)$ の $x$ 方向変化では, 中心線上では $x / h=7$ まで, また変動最大位置では $x / h=10$ まで増加した後, 下流方向に減少して, 前述の近似コルモゴロフ複雑度 $\mathrm{AK}$ と同様な挙動を示し，単調に変化しないため, 混合層 の乱流遷移進行の測度とするには無理がある. 図 17(b)の $y$ 方向変化の中で, 特徽的なものは $x / h=3$ の分布であ り，ポテンシャルコアであるノズル中心で低く，ノズル端面位置で大きく，この間の遷移進行を示している.

\section{5. 乱流の PDF 方程式に基づくシャノンエントロピー方程式について}

乱れ場の理解は乱れエネルギー方程式に基づいた乱れエネルギー生成，散冕，移動などの解釈により大きく進 展した(Townsend, 1956)(Rotta, 1962). 一方，これまでに行なわれた乱流シャノンエントロピーの研究は，それ自 身で完結した分布に関するものであって乱れ場の力学と方程式的には結びついていない，そこで乱れエネルギー 方程式と同様に乱流場のシャノンエントロピー方程式を導いて，得られた方程式について定性的に考察すること が，シャノンエントロピーの乱流場に於ける物理的理解の手がかりを与えてくれると期待されるので，以下でこ れを導出する．なお前述の開水路乱流の平均速度分布の誘導ではシャノンエントロピー最大值原理を用いたもの

で(Chiu, 1987), シャノンエントロピーの乱流場の式を調べたものではない.

以下ではテンソル記号を用いるために，前章までの記号とは異なる記号を用いる．対応は，

$$
\boldsymbol{u}=(u, v, w) \rightarrow\left(u_{1}, u_{2}, u_{3}\right)
$$




$$
\boldsymbol{x}=(x, y, z) \rightarrow\left(x_{1}, x_{2}, x_{3}\right)
$$

である. Pope の本(Pope, 2000)の記号に合わせて $\boldsymbol{u}$ の標本空間を $\boldsymbol{v}=\left(v_{1}, v_{2}, v_{3}\right)$ で表す．従って $v_{i}$ は $x_{i}, t$ と同じ独立 変数である. 変動速度の確率密度関数 PDFをPope に従って $g$ と書く．すなわち

$$
g(v ; x, t) \Delta v
$$

に於いて $\boldsymbol{x}, t$ は乱流場の物理的時空点を指している．式（7a） は変動速度の実現值 $\boldsymbol{u}=\left(u_{i}\right)$ の各成分が

$$
v_{i} \leqq u_{i}<v_{i}+\Delta v_{i}
$$

となる確率を表す。なお，これは連続場であることを注意する.

式を簡潔に示すために演算子記号 $\mathscr{L}, \mathscr{M}$ を導入すると， $g$ の方程式はナビア・ストークス方程式を用いて次 の形となる(Pope, 2000).

$$
\mathscr{L}(g)=\mathscr{M}(g)-\frac{\partial}{\partial v_{i}}\left(g C_{i}\right)
$$

ここに各記号は次式を意味するものとする.

$$
\begin{aligned}
& \mathscr{L}=\frac{\partial}{\partial t}+v_{i} \frac{\partial}{\partial x_{i}}+\left\langle U_{i}\right\rangle \frac{\partial}{\partial x_{i}} \\
& \mathscr{M}=A_{j, i} v_{i} \frac{\partial}{\partial v_{j}}-B_{i j, i} \frac{\partial}{\partial v_{j}} \\
& A_{j, i}=\frac{\partial\left\langle U_{j}\right\rangle}{\partial x_{i}}, \quad B_{i j, i}=\frac{\partial}{\partial x_{i}}\left\langle u_{i} u_{j}\right\rangle \\
& C_{i}=\left\langle v \nabla^{2} u_{i}-\frac{1}{\rho} \frac{\partial p^{\prime}}{\partial x_{i}} \mid v\right\rangle
\end{aligned}
$$

$\left\langle U_{i}\right\rangle$ は平均速度の $i$ 成分, $p$ ' は変動圧力である. $A_{j, i}$ は平均速度の空間勾配, $B_{i j, i}$ はレイノルズ応力テンソルの空

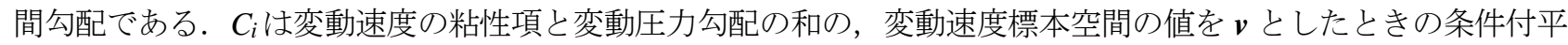
均である.

次のように $h$ を導入する.

$$
h=-g \log g
$$

$(\boldsymbol{x}, t)$ におけるシャノンエントロピー $H$ は，そこでの $h$ を標本空間全体に亘って積分した次式で与えられる.

$$
H=\iiint h d v_{1} d v_{2} d v_{3}
$$


ここでは統計力学に於いて Boltzmann 方程式から Bolzmann-Gibbs エントロピーを導く方法に従い，式（8）の

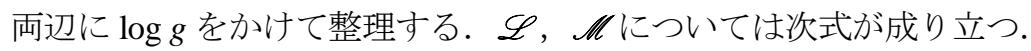

$$
(\log g) \mathscr{L}(g)=\mathscr{L}(g \log g)-\mathscr{L}(g), \quad(\log g) \mathscr{M}(g)=\mathscr{M}(g \log g)-\mathscr{M}(g)
$$

これは例えば

$$
(\log g) v_{i} \frac{\partial g}{\partial x_{i}}=v_{i}\left\{\frac{\partial}{\partial x_{i}}(g \log g)-\frac{\partial g}{\partial x_{i}}\right\}
$$

が成り立ち, 他の項についても同様な計算が可能なことから分かる． $C_{i}$ 項については次のように変形する.

$$
(\log g)\left(-\frac{\partial g}{\partial v_{i}} C_{i}-g \frac{\partial C_{i}}{\partial v_{i}}\right)=-\frac{\partial}{\partial v_{i}}\left(C_{i} g \log g\right)+C_{i} \frac{\partial g}{\partial v_{i}}
$$

これらの整理を行なった式と式（8）を辺々加え，それに式（10）の定義を代入すれば $h$ 方程式が次のように導 かれる。

$$
\mathscr{L}(h)=\mathscr{M}(h)-\frac{\partial}{\partial v_{i}}\left(h C_{i}\right)+g \frac{\partial C_{i}}{\partial v_{i}}
$$

それぞれを元の具体形にすると次式となる.

$$
\frac{\partial h}{\partial t}+v_{i} \frac{\partial h}{\partial x_{i}}+\left\langle U_{i}\right\rangle \frac{\partial h}{\partial x_{i}}=v_{i} \frac{\partial\left\langle U_{j}\right\rangle}{\partial x_{i}} \frac{\partial h}{\partial v_{j}}-\frac{\partial\left\langle u_{i} u_{j}\right\rangle}{\partial x_{i}} \frac{\partial h}{\partial v_{j}}-\frac{\partial}{\partial v_{i}}\left(h\left\langle v \nabla^{2} u_{i}-\frac{1}{\rho} \frac{\partial p^{\prime}}{\partial x_{i}} \mid v\right\rangle\right)+g \frac{\partial}{\partial v_{i}}\left\langle v \nabla^{2} u_{i}-\frac{1}{\rho} \frac{\partial p^{\prime}}{\partial x_{i}} \mid \boldsymbol{v}\right\rangle
$$

式（14）の左辺は，それぞれ $h$ 非定常変化，標本空間での対流，物理空間での対流を意味する. 右辺第 1 項は テンソル $\nabla\langle\boldsymbol{U}\rangle$ と, $\boldsymbol{v}$ と $\nabla h$ のテンソル積とのテンソル内積を意味する. ここで $\partial\left\langle U_{j}\right\rangle / \partial x_{i}$ を対称テンソルと非対 称テンソルに分解することにより，右辺第 1 項は次式となる.

$$
\frac{1}{2}\left(\frac{\partial\left\langle U_{j}\right\rangle}{\partial x_{i}}+\frac{\partial\left\langle U_{i}\right\rangle}{\partial x_{j}}\right) v_{i} \frac{\partial h}{\partial v_{j}}+\frac{1}{2}\left(\frac{\partial\left\langle U_{j}\right\rangle}{\partial x_{i}}-\frac{\partial\left\langle U_{i}\right\rangle}{\partial x_{j}}\right) v_{i} \frac{\partial h}{\partial v_{j}}
$$

すなわち物理空間での流体要素の変形速度テンソルが関与する変化と回転テンソル（渦度に相当）が関与する変 化に分けられる. 
右辺第 2 項はレイノルズ応カテンソルの物理空間変化と $h$ の標本空間変化との積を示し，シャノンエントロピ 一変化に際してもレイノルズ応力が重要であることを意味している. 右辺第 3 項は粘性と変動圧力勾配の関与を 示寸．右辺第 4 項はPDF $g$ が残っており， $h$ のみの方程式は得られないことを示す．

式（14）を標本空間全体に亘って積分すると式（11）の $H$ の変化の方程式が導かれる. 式（14）の左辺につい てはこれは

$$
\left(\frac{\partial}{\partial t}+\left\langle U_{i}\right\rangle \frac{\partial}{\partial x_{i}}\right) \iiint h d v_{1} d v_{2} d v_{3}=\frac{\partial H}{\partial t}+\left\langle U_{i}\right\rangle \frac{\partial H}{\partial x_{i}}
$$

と,

$$
\frac{\partial}{\partial x_{i}} \iiint v_{i} h d v_{1} d v_{2} d v_{3}
$$

となる. 式（16a）は物理空間での通常の $H$ の非定常及び対流的変化を意味する. 式（16b）は $\boldsymbol{v}$ 空間での $h$ の 1 次モーメントの物理空間での変化率を意味する. PDF のモーメントと同じで, この量はこの積分值が存在する時 にのみ意味を持つ．右辺の各項の積分についても同様な注意が必要である．また式（16a）のように $H$ を陽に表 すことは困難であるので式（14）の hの式のみで調べることになろう.

\section{6. 結 論}

2 次元噴流出口に形成される混合層の層流一乱流遷移過程について, 前報のコルモゴロフ複雑度による解析(一 宮, 中村, 2012)(Ichimiya and Nakamura, 2013)に続いて, 情報論的量を用いた解析を行い, 以下の結論を得た.

(1)変動速度の確率分布のシャノンエントロピーは, 混合層の乱流遷移過程において単調に増加して, 乱流遷移 の測度となり得る.

(2)変動速度の順列エントロピーは下流に進むと, 増加, 減少, 再増加, 再減少と変化するが, これは混合層の 乱流遷移過程における変動速度の増加や，周期変動から不規則変動への様式の変化を反映している.

(3)変動速度の確率密度関数の KL ダイバージェンスは, 初めは増加するが, 最大となった後は下流で減少して, 混合層の乱流遷移過程を通して単調には変化しない.

(4)シャンノンエントロピーが乱流場で満たすべき方程式を導き, レイノルズ応力との関連など幾つかの考察を 加えた.

今後は, 他の乱流場にも本論文の手法を適用し，解析をする計画である. また方程式（16）の境界層近似形や 等方性乱流場の場合の式を導き，各項の物理的意味を明らかにすることが望まれる.

\section{文献}

Amigó, J. M., Permutation Complexity in Dynamical Systems (2010), Springer.

甘利俊一, 情報理論 (1970), p. 8, ダイヤモンド社.

Bandt, C. and Pompe, B., Permutation entropy: A natural complexity measure for time series, Physical Review Letters, Vol. 88, No. 17 (2002), 174102.

Blackwelder, R. F. and Kaplan, R. E., On the wall structure of the turbulent boundary layer, Journal of Fluid Mechanics, Vol. 76, Part 1 (1976), pp. 89-112.

Brillouin, L., Science and Information Theory, 2nd ed. (1956), Dover.

Buxton, O. R. H., Modulation of the velocity gradient tensor by concurrent large-scale velocity fluctuations in a turbulent mixing layer, Journal of Fluid Mechanics, Vol. 777 (2015), DOI: 10.1017/jfm.2015.357. 
Cao, Y., Tung, W., Gao, J. B., Protopopescu, V. A. and Hively, L. M., Detecting dynamical changes in time series using the permutation entropy, Physical Review E, Vol. 70, No. 4 (2004), 046217.

Cerbus, R. T. and Goldburg, W. I., Information content of turbulence, Physical Review E, Vol. 88, No. 5 (2013), 053012.

Cerbus, R. T. and Goldburg, W. I., Predicting two-dimensional turbulence, Physical Review E, Vol. 91, No. 4 (2015), 043003.

Cerbus, R. T. and Goldburg, W. I., Information theory demonstration of the Richardson cascade, arXiv:1602.02980 (2016).

Chiu, C., Entropy and probability concepts in hydraulics, Journal of Hydraulic Engineering, Vol. 113, No. 5 (1987), pp. $583-600$.

Corke, T. C. and Guezennec, Y. G., Discrimination of coherent features in turbulent boundary layers by the entropy method, AIAA Journal, Vol. 24, No. 3 (1986), pp. 377-382.

Dimotakis, P. E., Miake-Lye, R. C. and Papantoniou, D. A., Structure and dynamics of round turbulent jets, Physics of Fluids, Vol.26, No. 11 (1983), pp. 3185-3192.

Granero-Belinchon, C., Roux, S. G. and Garnier, N. B., Scaling of information in turbulence, Europhysics Letters, Vol. 115, No. 5 (2016), 58003.

Gray, R. M., Entropy and Information Theory (1990), p. 21, Springer-Verlag.

韓太舜, 小林欣吾, 情報と符号化の数理 (1999), p. 25, 培風館.

一宮昌司, 加藤敏宏, 森本努, 2 次元噴流出口混合層に及ぼす局所周期摚乱の効果, 日本機械学会論文集 B 編, Vol. 77, No. 775 (2011a), pp. 424-436.

一宮昌司，鎌田慎也，岡島昌芳，大㟝貴之，2次元噴流出口混合層に及ぼす局所周期擋乱の効果（乱流遷移過程の 空間構造と定量的表示），日本機械学会論文集 B 編, Vol. 77, No. 779 (2011b), pp. 1457-1471.

Ichimiya, M., Kato, T. and Morimoto, T., Effect of local periodic disturbance on mixing layer at exit of two-dimensional jet, Journal of Fluid Science and Technology, Vol. 6, No. 6 (2011), pp. 887-901.

一宮昌司，中村育雄，コルモゴロフ複雑度による乱流のランダムさ表現（混合層の場合），日本機械学会論文集 B 編, Vol. 78, No. 788 (2012), pp. 794-810.

Ichimiya, M., Kamada, S., Okajima, A. and Osaki, T., Effect of local periodic disturbance on mixing layer downstream of two-dimensional jet (Spatial structure and quantitative representation of laminar-turbulent transition process), Journal of Fluid Science and Technology, Vol. 8, No. 1 (2013a), pp. 90-105.

一宮昌司，三浦武紘，鎌田慎也，2次元噴流出口混合層に及ぼす局所周期擋乱の効果（擋乱振幅と周波数の影響）， 日本機械学会論文集 B 編, Vol. 79, No. 806 (2013b), pp. 2093-2108.

Ichimiya, M. and Nakamura, I., Randomness representation in turbulent flows with Kolmogorov complexity (In mixing layer), Journal of Fluid Science and Technology, Vol. 8, No. 3 (2013), pp. 407-422.

一宮昌司, 中村育雄, 原達彦, コルモゴロフ複雑度による乱流のランダムさ表現 (平板上単一突起下流の乱流くさ びの場合），日本機械学会論文集, Vol. 80, No. 813 (2014), DOI: 10.1299/transjsme.2014fe0117.

Ichimiya, M., Sakai, H. and Oohara, T., Properties of the laminar-turbulent transition in a mixing layer by the low-frequency disturbance (Effect of the anti-symmetrical disturbance), Journal of Fluid Science and Technology, Vol. 9, No. 3 (2014), DOI: $10.1299 /$ jfst.2014jfst0038.

一宮昌司，中村育雄，田村和大，コルモゴロフ複雑度による乱流のランダムさ表現（円管助走部境界層の乱流遷移 の場合），日本機械学会論文集, Vol. 81, No. 828 (2015), DOI:10.1299/transjsme.15-00172.

Ikeda, K. and Matsumoto, K., Information theoretical characterization of turbulence, Physical Review Letters, Vol. 62, No. 19 (1989), pp. 2265-2268.

Jaynes, E.T., Probability Theory: The Logic of Science (2003), Cambridge University Press.

Kolmogorov, A. N., Three approaches to the quantitative definition of information, Problems of Information Transmission, Vol. 1, No. 1 (1965), pp. 1-7.

Kolmogorov, A. N., Combinatorial foundations of information theory and the calculus of probabilities, Russian Mathematical Surveys, Vol. 38, No. 4 (1983), pp. 29-40.

Leopold, L. B. and Langbein, W. B., The concept of entropy in landscape evolution, Professional Paper 500-A, USGS Numbered Series, United States Government Printing Office, Washington (1962), pp. A1-A20.

$\mathrm{Li}, \mathrm{Q}$. and Fu, Z., Permutation entropy and statistical complexity quantifier of nonstationarity effect in the vertical velocity records, Physical Review E, Vol. 89, No. 1 (2014), 012905.

Lindgren, B., Johansson, A. V. and Tsuji, Y., Universality of probability density distributions in the overlap region in high Reynolds number turbulent boundary layers, Physics of Fluids, Vol. 16, No. 7 (2004), pp. 2587-2591.

Nakamura, I. and Tsuji, Y., Some progress in the research of the dynamical structure in wall turbulence, JSME International 
Journal, Ser. B, Vol. 38, No.3 (1995), pp. 335-345.

Oberlack, M., A unified approach for symmetries in plane parallel shear flows, Journal of Fluid Mechanics, Vol. 427 (2001), pp. 299-328.

Pope, S. B., Turbulent Flows (2000), Cambridge University Press.

Riedl, M., Müller, A. and Wessel, N., Practical considerations of permutation entropy: A tutorial review, European Physical Journal Special Topics, Vol. 222 (2013), pp. 249-262.

Rosso, O. A., Larrondo, H. A., Martin, M. T., Plastino, A. and Fuentes, M. A., Distinguishing noise from chaos, Physical Review Letters, Vol. 99, No. 15 (2007), 154102.

Rotta, J. C., Turbulent boundary Layers in incompressible flow, Ferri, A., Kuchemann, D. and Sterne, L. H. G. ed., Progress in Aeronautical Sciences, Vol. 2 (1962), Pergamon Press.

Sato, H., and Saito, H., Fine-structure of energy spectra of velocity fluctuations in the transition region of a two-dimensional wake, Journal of Fluid Mechanics, Vol. 67, Part 3 (1975), pp. 539-559.

Shannon, C. E. and Weaver, W., The Mathematical Theory of Communication (1949), p. 18, University of Illinois Press. (日 本語訳, 植松友彦訳, 通信の数学的理論 (2009), pp. 88, 筑摩書房.)

Shannon, C. E., A mathematical theory of communication, The Bell System Technical Journal, Vol. 27 (1948), pp. 379-423, pp. 623-656.

Singh, V. P., Hydrologic synthesis using entropy theory: Review, Journal of Hydrologic Engineering, Vol. 16, No. 5 (2011), pp. 421-433.

Singh, V. P., Entropy Theory and its Application in Environmental and Water Engineering (2013), John Wiley and Sons.

高岡詠子, シャノンの情報理論入門 (2012), p. 53, 講談社.

Townsend, A. A., The Structure of Turbulent Shear Flow (1956), Cambridge University Press.

Tsuji, Y. and Nakamura, I., Probability density function in the log-law region of low Reynolds number turbulent boundary layer, Physics of Fluids, Vol. 11, No. 3 (1999), pp. 647-658.

Tsuji, Y., Lindgren, B. and Johansson, A. V., Self-similar profile of probability density functions in zero-pressure gradient turbulent boundary layers, Fluid Dynamics Research, Vol. 37, No. 5 (2005), pp. 293-316.

Vitányi, P., 渡辺治訳, 圧縮度に基づいた汎用な類似度測定法, 数理科学, No. 519 (2006), pp. 54-59.

Weck, P. J., Schaffner, D. A. and Brown, M. R., Permutation entropy and statistical complexity analysis of turbulence in laboratory plasmas and the solar wind, Physical Review E, Vol. 91, No. 2 (2015), 023101.

Wesson, K. H., Katul, G. G. and Siqueira, M., Quantifying organization of atmospheric turbulent eddy motion using nonlinear time series analysis, Boundary-Layer Meteorology, Vol. 106, Issue 3 (2003), pp. 507-525.

Wijesekera, M. W. and Dillon, T. M., Shannon entropy as an indicator of age for turbulent overturns in the oceanic thermocline, Journal of Geophysical Research, Vol. 102, No. C2 (1997), pp. 3279-3291.

Zanin, M., Zunino, L., Rosso, O.A. and Papo, D., Permutation entropy and its main biomedical and econophysics applications: A review, Entropy, Vol.14, No.8 (2012), pp. 1553-1577.

\section{References}

Amigó, J. M., Permutation Complexity in Dynamical Systems (2010), Springer.

Amari, S., Information Theory (1970), p. 8, Diamondsha (in Japanese).

Bandt, C. and Pompe, B., Permutation entropy: A natural complexity measure for time series, Physical Review Letters, Vol. 88, No. 17 (2002), 174102.

Blackwelder, R. F. and Kaplan, R. E., On the wall structure of the turbulent boundary layer, Journal of Fluid Mechanics, Vol. 76, Part 1 (1976), pp. 89-112.

Brillouin, L., Science and Information Theory, 2nd ed. (1956), Dover.

Buxton, O. R. H., Modulation of the velocity gradient tensor by concurrent large-scale velocity fluctuations in a turbulent mixing layer, Journal of Fluid Mechanics, Vol. 777 (2015), DOI: 10.1017/jfm.2015.357.

Cao, Y., Tung, W., Gao, J. B., Protopopescu, V. A. and Hively, L. M., Detecting dynamical changes in time series using the permutation entropy, Physical Review E, Vol. 70, No. 4 (2004), 046217.

Cerbus, R. T. and Goldburg, W. I., Information content of turbulence, Physical Review E, Vol. 88, No. 5 (2013), 053012.

Cerbus, R. T. and Goldburg, W. I., Predicting two-dimensional turbulence, Physical Review E, Vol. 91, No. 4 (2015), 043003.

Cerbus, R. T. and Goldburg, W. I., Information theory demonstration of the Richardson cascade, arXiv:1602.02980 (2016). 
Chiu, C., Entropy and probability concepts in hydraulics, Journal of Hydraulic Engineering, Vol. 113, No. 5 (1987), pp. 583-600.

Corke, T. C. and Guezennec, Y. G., Discrimination of coherent features in turbulent boundary layers by the entropy method, AIAA Journal, Vol. 24, No. 3 (1986), pp. 377-382.

Dimotakis, P. E., Miake-Lye, R. C. and Papantoniou, D. A., Structure and dynamics of round turbulent jets, Physics of Fluids, Vol.26, No. 11 (1983), pp. 3185-3192.

Granero-Belinchon, C., Roux, S. G. and Garnier, N. B., Scaling of information in turbulence, Europhysics Letters, Vol. 115, No. 5 (2016), 58003.

Gray, R. M., Entropy and Information Theory (1990), p. 21, Springer-Verlag.

Han, T. S. and Kobayashi, K., Mathematics of Information and Coding (1999), p. 25, Baifukan (in Japanese).

Ichimiya, M., Kato, T. and Morimoto, T., Effect of local periodic disturbance on mixing layer at exit of two-dimensional jet, Transactions of the Japan Society of Mechanical Engineers, Series B, Vol. 77, No. 775 (2011a), pp. $424-436$ (in Japanese).

Ichimiya, M., Kamada, S., Okajima, A. and Osaki, T., Effect of local periodic disturbance on mixing layer downstream of two-dimensional jet (Spatial structure and quantitative representation of laminar-turbulent transition process), Transactions of the Japan Society of Mechanical Engineers, Series B, Vol. 77, No. 779 (2011b), pp. 1457-1471 (in Japanese).

Ichimiya, M., Kato, T. and Morimoto, T., Effect of local periodic disturbance on mixing layer at exit of two-dimensional jet, Journal of Fluid Science and Technology, Vol. 6, No. 6 (2011), pp. 887-901.

Ichimiya, M. and Nakamura, I., Randomness representation in turbulent flows with Kolmogorov complexity (In mixing layer), Transactions of the Japan Society of Mechanical Engineers, Series B, Vol. 78, No. 788 (2012), pp. $794-810$ (in Japanese).

Ichimiya, M., Kamada, S., Okajima, A. and Osaki, T., Effect of local periodic disturbance on mixing layer downstream of two-dimensional jet (Spatial structure and quantitative representation of laminar-turbulent transition process), Journal of Fluid Science and Technology, Vol. 8, No. 1 (2013a), pp. 90-105.

Ichimiya, M., Miura, T. and Kamada, S., Effect of local periodic disturbance on mixing layer downstream of two-dimensional jet (Effect of amplitude and frequency of the disturbance), Transactions of the Japan Society of Mechanical Engineers, Series B, Vol. 79, No. 806 (2013b), pp. 2093-2108 (in Japanese).

Ichimiya, M. and Nakamura, I., Randomness representation in turbulent flows with Kolmogorov complexity (In mixing layer), Journal of Fluid Science and Technology, Vol. 8, No. 3 (2013), pp. 407-422.

Ichimiya, M., Nakamura, I. and Hara, T., Randomness representation in turbulent flows with Kolmogorov complexity (In turbulence wedge developed from a single roughness element on a flat plate), Transactions of the JSME (in Japanese), Vol. 80, No. 813 (2014), DOI: 10.1299/transjsme.2014fe0117.

Ichimiya, M., Sakai, H. and Oohara, T., Properties of the laminar-turbulent transition in a mixing layer by the low-frequency disturbance (Effect of the anti-symmetrical disturbance), Journal of Fluid Science and Technology, Vol. 9, No. 3 (2014), DOI: 10.1299/jfst.2014jfst0038.

Ichimiya, M., Nakamura, I. and Tamura, T., Randomness representation in turbulent flows with Kolmogorov complexity (In laminar-turbulent transition due to periodic injection in an inlet boundary layer in a circular pipe), Transactions of the JSME (in Japanese), Vol. 81, No. 828 (2015), DOI:10.1299/transjsme.15-00172.

Ikeda, K. and Matsumoto, K., Information theoretical characterization of turbulence, Physical Review Letters, Vol. 62, No. 19 (1989), pp. 2265-2268.

Jaynes, E.T., Probability Theory: The Logic of Science (2003), Cambridge University Press.

Kolmogorov, A. N., Three approaches to the quantitative definition of information, Problems of Information Transmission, Vol. 1, No. 1 (1965), pp. 1-7.

Kolmogorov, A. N., Combinatorial foundations of information theory and the calculus of probabilities, Russian Mathematical Surveys, Vol. 38, No. 4 (1983), pp. 29-40.

Leopold, L. B. and Langbein, W. B., The concept of entropy in landscape evolution, Professional Paper 500-A, USGS Numbered Series, United States Government Printing Office, Washington (1962), pp. A1-A20.

$\mathrm{Li}, \mathrm{Q}$. and $\mathrm{Fu}, \mathrm{Z}$., Permutation entropy and statistical complexity quantifier of nonstationarity effect in the vertical velocity records, Physical Review E, Vol. 89, No. 1 (2014), 012905.

Lindgren, B., Johansson, A. V. and Tsuji, Y., Universality of probability density distributions in the overlap region in high 
Reynolds number turbulent boundary layers, Physics of Fluids, Vol. 16, No. 7 (2004), pp. 2587-2591.

Nakamura, I. and Tsuji, Y., Some progress in the research of the dynamical structure in wall turbulence, JSME International Journal, Ser. B, Vol. 38, No.3 (1995), pp. 335-345.

Oberlack, M., A unified approach for symmetries in plane parallel shear flows, Journal of Fluid Mechanics, Vol. 427 (2001), pp. 299-328.

Pope, S. B., Turbulent Flows (2000), Cambridge University Press.

Riedl, M., Müller, A. and Wessel, N., Practical considerations of permutation entropy: A tutorial review, European Physical Journal Special Topics, Vol. 222 (2013), pp. 249-262.

Rosso, O. A., Larrondo, H. A., Martin, M. T., Plastino, A. and Fuentes, M. A., Distinguishing noise from chaos, Physical Review Letters, Vol. 99, No. 15 (2007), 154102.

Rotta, J. C., Turbulent boundary Layers in incompressible flow, Ferri, A., Kuchemann, D. and Sterne, L. H. G. ed., Progress in Aeronautical Sciences, Vol. 2 (1962), Pergamon Press.

Sato, H., and Saito, H., Fine-structure of energy spectra of velocity fluctuations in the transition region of a two-dimensional wake, Journal of Fluid Mechanics, Vol. 67, Part 3 (1975), pp. 539-559.

Shannon, C. E. and Weaver, W., The Mathematical Theory of Communication (1949), p. 18, University of Illinois Press.

Shannon, C. E., A mathematical theory of communication, The Bell System Technical Journal, Vol. 27 (1948), pp. 379-423, pp. 623-656.

Singh, V. P., Hydrologic synthesis using entropy theory: Review, Journal of Hydrologic Engineering, Vol. 16, No. 5 (2011), pp. $421-433$.

Singh, V. P., Entropy Theory and its Application in Environmental and Water Engineering (2013), John Wiley and Sons.

Takaoka, E., Information for Shannon's Information Theory (2012), p. 53, Kodansha (in Japanese).

Townsend, A. A., The Structure of Turbulent Shear Flow (1956), Cambridge University Press.

Tsuji, Y. and Nakamura, I., Probability density function in the log-law region of low Reynolds number turbulent boundary layer, Physics of Fluids, Vol. 11, No. 3 (1999), pp. 647-658.

Tsuji, Y., Lindgren, B. and Johansson, A. V., Self-similar profile of probability density functions in zero-pressure gradient turbulent boundary layers, Fluid Dynamics Research, Vol. 37, No. 5 (2005), pp. 293-316.

Vitányi, P., (translated in Japanese, Watanabe, O.) Universal similarity measurement based on complexity, Mathematical Sciences, No. 519 (2006), pp. 54-59 (in Japanese).

Weck, P. J., Schaffner, D. A. and Brown, M. R., Permutation entropy and statistical complexity analysis of turbulence in laboratory plasmas and the solar wind, Physical Review E, Vol. 91, No. 2 (2015), 023101.

Wesson, K. H., Katul, G. G. and Siqueira, M., Quantifying organization of atmospheric turbulent eddy motion using nonlinear time series analysis, Boundary-Layer Meteorology, Vol. 106, Issue 3 (2003), pp. 507-525.

Wijesekera, M. W. and Dillon, T. M., Shannon entropy as an indicator of age for turbulent overturns in the oceanic thermocline, Journal of Geophysical Research, Vol. 102, No. C2 (1997), pp. 3279-3291.

Zanin, M., Zunino, L., Rosso, O.A. and Papo, D., Permutation entropy and its main biomedical and econophysics applications: A review, Entropy, Vol.14, No.8 (2012), pp. 1553-1577. 